\title{
Antykonkurencyjne innowacje - oksymoron czy realne wyzwanie prawa antymonopolowego?
}

\section{Wprowadzenie}

Jednym z kanonów współczesnej polityki gospodarczej jest promowanie innowacji, rozumianych (w szerokim, dwupłaszczyznowym ujęciu) jako wynik zastosowania postępu wiedzy (innowacje jako rezultat), a zarazem jako działania poprzedzające tenże rezultat, obejmujące powstanie pomysłu, prace badawczo-rozwojowe i projektowe, produkcję i upowszechnianie (innowacje jako proces) ${ }^{1}$. Innowacje są niezbędnym, dynamicznym składnikiem otwartej i konkurencyjnej gospodarki rynkowej, zwłaszcza w sektorach wysokich technologii (np. farmaceutycznym,

${ }^{1}$ Zob. np. E. Stawasz, G. Niedbalska, Działalność innowacyjna, w: Innowacje i transfer technologii. Słownik pojęć, pod red. K.B. Matusiak, Warszawa 2011, s. 54; S. Gomułka, Teoria innowacji i wzrostu gospodarczego, Warszawa 1998, s. 17 i n. Także w ujęciu słownikowym innowacje mogą oznaczać zarówno swoisty proces („wprowadzenie nowego rozwiązania”), jak i rezultat („nowe rozwiązanie”), zob. Wielki słownik języka polskiego, http://wsjp.pl/index.php?id_hasla=37298\&ind=0\&w_szukaj=innowacja (dostęp: 22 III 2017). W ujęciu jednopłaszczyznowym (według tzw. metodologii Oslo) innowacje oznaczają wdrożenie nowego lub znacząco udoskonalonego produktu (wyrobu lub usługi) lub procesu, nowej metody marketingowej lub nowej metody organizacyjnej w praktyce gospodarczej, organizacji miejsca pracy lub stosunkach z otoczeniem, zob. Podrecznik Oslo. Zasady gromadzenia i interpretacji danych dotyczacych innowacji, Warszawa 2008, s. 48. Według tej koncepcji pojęciu innowacji towarzyszy pokrewne pojęcie działalności innowacyjnej, przez którą rozumie się całokształt działań naukowych, technicznych, organizacyjnych, finansowych i komercyjnych, które prowadzą lub mają w zamierzeniu prowadzić do wdrażania innowacji (ibidem, s. 49). 
biotechnologicznym oraz informatycznym), a zarazem najważniejszym czynnikiem wzrostu i rozwoju gospodarczego, co przekłada się na wzrost dobrobytu społeczeństwa ${ }^{2}$. Nie ulega wątpliwości, że od pokoleń innowacje pozostają główną determinantą dobrobytu ludzkości. Co prawda, ekonomiści wciąż spierają się, która forma organizacji procesów gospodarczych - monopol czy konkurencja - pobudza (stymuluje) bardziej innowacyjność (tj. zdolność do tworzenia i wdrażania innowacji, jak również ich absorpcji ${ }^{3}$, niemniej jednak panuje szeroki konsensus, że korzyści osiągane dzięki innowacjom dalece przewyższają pożytki z wszelkich innych źródeł postępu gospodarczego ${ }^{4}$. Emanacją tego stanu rzeczy jest swoista kontradykcja w relacjach między prawem własności intelektualnej (w tym przemysłowej) i prawem antymonopolowym, które łączy zbieżny cel: wspieranie i promowanie innowacji, a zarazem dzieli odmienność środków służących jego urzeczywistnianiu. O ile prawo własności intelektualnej opiera się na zapewnieniu jej dysponentowi prawnie określonej wyłączności (quasi-monopolu) korzystania z tej własności (np. wynalazku), o tyle prawo antymonopolowe zakłada konieczność przeciwdziałania nadmiernej koncentracji i ograniczeniom konkurencji na rynku ${ }^{5}$.

${ }^{2}$ Zob. A. Devlin, M. Jacobs, Anticompetitive Innovation and the Quality of Invention, "Berkeley Technology Law Journal” 2012, vol. 27, no. 1, s. 3; G. Bernstein, In the Shadow of Innovation, "Cardozo Law Review" 2010, vol. 31, no. 6, s. 2258, oraz źródła cytowane w przypisie 3 niniejszego opracowania. Tezę o prorozwojowym charakterze innowacji potwierdzają dane empiryczne, zob. M. Stec, Innowacyjność krajów Unii Europejskiej, "Gospodarka Narodowa" 2006, nr 11-12, s. 45 i n.

${ }^{3}$ Egzemplifikacją tego sporu jest polemika między J.A. Schumpeterem (Kapitalizm, socjalizm, demokracja, Warszawa 2009) i K.J. Arrowem (Economic Welfare and the Allocation of Resources for Invention, w: The Rate and Direction of Inventive Activity: Economic and Social Factors, Princeton 1962, s. 619 i n.); zob. też J.B. Baker, Beyond Schumpeter vs. Arrow: How Antitrust Fosters Innovation, "Antitrust Law Journal” 2007, vol. 74, no. 3, s. 575 i n.; J. Tang, Competition and Innovation Behaviour, "Research Policy” 2006, vol. 35, no. 1, s. 68 i n.; J. Czerniak, Wpływ presji konkurencyjnej na innowacyjność gospodarek krajów OECD, "Annales Universitatis Mariae Curie-Skłodowska" 2011, t. XLV, nr 1, s. 77 i n. W kwestii definiowania innowacyjności zob. P. Niedzielski, Innowacyjność, w: Innowacje i transfer technologii..., s. 119 i n.

${ }^{4}$ A. Devlin, M. Jacobs, Anticompetitive Innovation..., s. 3.

${ }^{5} \mathrm{O}$ relacjach między prawem antymonopolowym i prawem własności intelektualnej zob. D. Miąsik, Stosunek prawa ochrony konkurencji do prawa własności intelektualnej, Warszawa 2012; K.N. Hylton, Antitrust and Intellectual Property: A Brief Introduction, w: Cambridge Handbook of Antitrust, Intellectual Property and High Tech, ed. by R.D. Blair, D.D. Sokol, Cambridge 2017; T. Käseberg, Intellectual Property, Antitrust and Cumulative Innovation in the EU and the US, Oxford 2012; K. Czapracka, Intellectual Property and the Limits of Antitrust: 
W świetle powyższych uwag zaskakujący i wręcz kontrowersyjny wydawać się może pogląd dopuszczający kwestionowanie innowacji na podstawie zarzutu o ich sprzeczność z prawem antymonopolowym (ergo uznający, że innowacje mogą być antykonkurencyjne). Paradoksalność tego założenia jest jednak pozorna. Jak bowiem wiadomo, zachowania rynkowe, które są generalnie uznawane za gospodarczo pożyteczne, konkurencyjne i zgodne z prawem antymonopolowym (np. silna konkurencja cenowa), w szczególnych okolicznościach mogą okazać się godnym napiętnowania deliktem antykonkurencyjnym (np. tzw. drapieżnictwem cenowym $)^{6}$. Nie inaczej jest $z$ innowacjami. Pogląd o ich bezpośrednim i notorycznie pozytywnym związku z postępem (dobrobytem społeczno-gospodarczym) nie wytrzymuje konfrontacji z rzeczywistością i wymaga $w$ związku z tym przewartościowania. Innowacje, w różnych epokach historii kojarzone $z$ aktywnością na rzecz dobra ludzkości, z czasem stały się wyjątkowo lukratywnym przedsięwzięciem - czymś na kształt świętego Graala przedsiębiorstw dążących do maksymalizacji sprzedaży ${ }^{7}$. Co więcej, od kilku dekad można też dostrzec inny fenomen: niejednokrotnie praktyki rynkowe kojarzone z innowacjami zaczynają służyć rywalizacji rynkowej, która zagraża już efektywnej konkurencji, a w konsekwencji - dobrobytowi społeczno-gospodarczemu. Innowacje nie zawsze są zatem "krokiem naprzód”, ale mogą być starannie zaplanowanym manewrem służącym pozbyciu się konkurencji ${ }^{8}$. Wobec tego zjawiska prawo antymonopolowe nie

A Comparative Study of US and EU Approaches, Cheltenham 2009; The Interface Between Intellectual Property Rights and Competition Policy, ed. by S.D. Anderman, Cambridge 2007.

${ }^{6}$ Report on Predatory Pricing, ICN 2008, http://www.internationalcompetitionnetwork. org/uploads/library/doc354.pdf (dostęp: 22 III 2017); Predatory Pricing, OECD 1989, http://www.oecd.org/competition/abuse/2375661.pdf (dostęp: 22 III 2017); P. Areeda, D.F. Turner, Predatory Pricing and Related Practices Under Section 2 of the Sherman Act, "Harvard Law Review" 1975, vol. 88, no. 4, s. 697 i n.; N. Szadkowski, Drapieżnictwo cenowe w teorii ekonomii i w praktyce orzeczniczej polskiego organu antymonopolowego, w: Konkurencja w gospodarce współczesnej, pod red. C. Banasińskiego, E. Stawickiego, Warszawa 2007, s. $287 \mathrm{i} \mathrm{n.}$

${ }^{7}$ C. Acuña-Quiroga, Predatory Innovation: A Step Beyond? (Understanding Competition in High-technology Markets), "International Review of Law Computers \& Technology" 2001, vol. 15, no. 1, s. 7. Ze względu na uniwersalny wymiar poruszanych tu zagadnień, dalece wykraczający poza uwarunkowania lokalne, używany będzie termin "przedsiębiorstwo" (w sensie podmiotowym), będący polskim odpowiednikiem stosowanego powszechnie za granicą anglojęzycznego określenia undertaking.

${ }_{8}^{8}$ Jaskrawym przykładem innowacji postrzeganych jako aberracja z przyczyn wykraczających poza względy ochrony konkurencji może być wdrożenie przez producentów materiału siewnego nasion uzyskiwanych w wyniku mutagenezy (przypadkowej mutacji 
może pozostawać obojętne, aczkolwiek z powodu złożonych uwarunkowań i osobliwej natury odnośnych praktyk, a zwłaszcza trudności $\mathrm{w}$ mierzeniu korzyści i strat $\mathrm{z}$ ograniczających konkurencję innowacji, teoria i praktyka tego prawa wciąż nie wypracowały względem nich spójnego stanowiska. Dość wspomnieć tu sygnalnie, że koncepcje monopolizacji czy też nadużycia pozycji dominującej, przybierających postać antykonkurencyjnych innowacji, były już w teorii i praktyce prawa antymonopolowego uznawane, odrzucane i rehabilitowane ${ }^{9}$. Jedno jest pewne: pytania, czy, i ewentualnie w jakich okolicznościach, prawo antymonopolowe powinno delegalizować aktywność innowacyjna, a w związku z tym jak odróżniać "dobre" innowacje od "złych", należą do najtrudniejszych i zarazem budzących najsilniejsze spory $\mathrm{w}$ doktrynie i orzecznictwie prawa antymonopolowego ${ }^{10}$. Już choćby $z$ tego powodu celowe wydaje się podjęcie próby szerszej refleksji na ten temat, którą sprowadzić można do odpowiedzi na pytanie zawarte w tytule niniejszego artykułu. Tym bardziej że zarzuty o niezgodne z regułami konkurencji strategie rynkowe przedsiębiorstw innowacyjnych, szczególnie w postaci drapieżnictwa wykluczającego z rynku konkurentów, nie są już czymś wyjątkowym (zwłaszcza w krajach wysoko rozwiniętych). Wprawdzie nie da się tego powiedzieć o Polsce, gdzie trudno o przykłady postępowań antymonopolowych, w których występowałby wyraźny konflikt między innowacjami (także chronionymi prawami wyłącznymi) a ochroną konkurencji, co do pewnego stopnia tłumaczy fakt, że w dziedzinie innowacyjności jesteśmy wciąż raczej krajem "na dorobku"11, niemniej jednak są przesłanki, by sądzić, iż ten

genów wywołanej promieniowaniem jonizującym lub chemikaliami), w celu uniknięcia wysoce restrykcyjnego reżimu, jakim w Europie objęto uprawy roślin poddanych transgenezie (celowej inżynierii genetycznej, GMO). Jak na ironię, produkty nowej technologii postrzegane bywają jako większe zagrożenie dla zdrowia publicznego niż produkty zastępowane, zob. D.L. Burk, Perverse Innovation, "William \& Mary Law Review” 2016, vol. 58, no. 1, s. 1 i n.

${ }^{9}$ D.A. Crane, Legal Rules for Predatory Innovation, "Concurrences" 2013, no. 4, s. 1, oraz przywoływane tam piśmiennictwo.

${ }^{10}$ Najgłośniejszym, a przy tym najbardziej spornym, przypadkiem ostatnich lat ilustrującym sygnalizowany problem były postępowania antymonopolowe prowadzone w Stanach Zjednoczonych i Unii Europejskiej (UE) w sprawie monopolizacji rynku (nadużywania pozycji dominującej) przez spółkę Microsoft.

${ }^{11}$ A. Jurkowska-Gomułka, T. Skoczny, A. Warzybok, Innowacje a ochrona konkurencji i konsumentów w warunkach członkostwa Polski w Unii Europejskiej, w: Innowacyjność polskiej gospodarki w okresie transformacji. Wybrane aspekty, pod red. A.H. Jasińskiego, Warszawa 2010, s. 191 i 257; zob. też D. Miąsik, Ustawa o ochronie konkurencji i konsumentów a prawo 
stan rzeczy może ulec zmianie, zwłaszcza po nadaniu innowacyjności polskiej gospodarki rangi jednego z priorytetów polityki rządu ${ }^{12}$. Niezależnie od pożądanych sukcesów $\mathrm{w}$ realizacji tego priorytetu tytułowe zagadnienie zasługuje na uwagę polskich interesariuszy (w tym przedsiębiorstw i konsumentów) także $\mathrm{z}$ tego względu, że w realiach współczesnej gospodarki nie są oni odseparowani od innowacji pochodzących z zagranicy, ze wszystkimi tego pozytywnymi i negatywnymi konsekwencjami. Trzeba przy tym mieć świadomość, że w ramach UE interwencje antymonopolowe w sprawach praktyk wiodących na świecie przedsiębiorstw innowacyjnych, ze względu na charakter i rangę tych spraw, a także zasady funkcjonowania Europejskiej Sieci Konkurencji, są (i zapewne pozostaną) domeną Komisji Europejskiej (dalej: KE lub Komisja), nawet jeśli ziszczą się plany wzmocnienia roli krajowych organów antymonopolowych w egzekwowaniu unijnych reguł konkurencji ${ }^{13}$.

własności intelektualnej - czy art. 2 ustawy jest w ogóle potrzebny?, „Internetowy Kwartalnik Antymonopolowy i Regulacyjny" 2012, nr 1(1), s. 58 i 59.

12 Zob. Strategia na rzecz Odpowiedzialnego Rozwoju do roku 2020 ( $z$ perspektywa do 2030 r.), s. 85 i n., https://www.mr.gov.pl/media/34300/SOR_2017_maly_internet_14072017_wstepPMM.pdf (dostęp: 20 III 2017); Ustawa z dnia 4 XI 2016 r. o zmianie niektórych ustaw określających warunki prowadzenia działalności innowacyjnej (Dz.U. poz. 1933). Symptomem większej aktywności Prezesa Urzędu Ochrony Konkurencji i Konsumentów (UOKiK) na rynkach nowych technologii (w sprawach potencjalnie antykonkurencyjnych innowacji) może być jego decyzja z 13 XII 2010 r. nr RWA 23/2010, dotycząca spółki Amadeus Polska. Jest ona największym w naszym kraju przedsiębiorstwem z branży elektronicznej dystrybucji produktów i usług turystycznych za pośrednictwem globalnego komputerowego systemu dystrybucyjnego - GDS, a zarazem jednym z producentów programu mid-office, który umożliwia biurom podróży korzystanie $\mathrm{z}$ danych zawartych $\mathrm{w}$ tym systemie. W związku z uprawdopodobnieniem, że spółka Amadeus, pobierając nieproporcjonalnie wyższe opłaty za dostęp do bazy danych generowanej przez system GDS od biur podróży korzystających z programów mid-office innych producentów, mogła uniemożliwiać lub utrudniać rozwój konkurencji na rynku sprzedaży tego typu oprogramowania, naruszając tym samym zakaz nadużywania pozycji dominującej, została zobowiązana do zaniechania tej praktyki. Na odnotowanie zasługuje też stanowisko Prezesa UOKiK wyrażające pogląd, że usługi spółki Uber Poland, oparte na innowacyjnej aplikacji mobilnej umożliwiającej zamawianie usług transportu samochodowego poprzez kojarzenie pasażerów z kierowcami korzystającymi z aplikacji, nie noszą znamion praktyki nastawionej na eliminowanie konkurencji, zob. Uber - stanowisko UOKiK, https://www.uokik.gov.pl/aktualnosci.php? news_id=12352 (dostęp: 28 III 2017).

${ }^{13}$ Zob. pkt 14 i 15 obwieszczenia Komisji w sprawie współpracy w ramach sieci organów ochrony konkurencji (Dz.Urz. WE C 101 z 27 IV 2004 r., s. 4: „Komisja jest w szczególności właściwa do prowadzenia działania, jeżeli [...] praktyki wywierają wpływ na konkurencję w więcej niż trzech państwach członkowskich. Ponadto Komisja jest szczególnie właściwym organem do prowadzenia sprawy, jeżeli [...] interes Wspólnoty 


\title{
1. Typy potencjalnie antykonkurencyjnych innowacji oraz ich antymonopolowa kwalifikacja
}

\begin{abstract}
Katalog potencjalnie antykonkurencyjnych zachowań rynkowych przedsiębiorstw angażujących się w działalność innowacyjną jest obszerny. Zachowania te mogą nosić znamiona wielostronnych (kolektywnych) praktyk ograniczających konkurencję (np. porozumień o współpracy badawczo-rozwojowej zakładających udostępnienie konkurentom posiadanych praw własności intelektualnej ${ }^{14}$ lub ugód patentowych utrudniających dostęp do innowacyjnych produktów ${ }^{15}$ ), a także antykonkurencyjnych operacji koncentracyjnych ${ }^{16}$. Sedno problemu ujętego
\end{abstract}

wymaga podjęcia przez Komisję decyzji dotyczącej opracowania wspólnotowej polityki konkurencji w związku z pojawieniem się nowej kwestii dotyczącej konkurencji lub w celu zapewnienia skutecznego egzekwowania") oraz dokument roboczy służb Komisji pt. Poprawa egzekwowania regut konkurencji przez organy ochrony konkurencji w państwach członkowskich - aspekty instytucjonalne i proceduralne, dołączony do komunikatu Komisji (SWD(2014)231 wersja ostateczna), 9 VII 2014, http://eur-lex.europa.eu/legal-content/ EN/TXT/PDF/?uri=CELEX:52014SC0231\&from=EN (dostęp: 20 III 2017).

${ }^{14}$ Zob. A. Jurkowska-Gomułka, T. Skoczny, A. Warzybok, op. cit., s. 187 i n.

${ }^{15}$ Chodzi w szczególności o ugody zawierające mechanizm odwróconych płatności aktualnym lub też potencjalnym konkurentom przez podmioty uprawnione z praw własności intelektualnej (ang. "pay-for-delay” settlements lub reverse payment settlements); szerzej M.K. Kolasiński, "Ugody patentowe o odwróconej płatności” w prawie antymonopolowym Unii Europejskiej na tle rozwiazań przyjętych w prawie amerykańskim, "Europejski Przegląd Sądowy" 2016, nr 5, s. 31 i n.; P. Wosik, Porozumienia pay-for-delay jako ograniczenie konkurencji ze względu na cel. Glosa do wyroku Sądu Unii Europejskiej z dnia 8 września 2016 r. w sprawie T-472/13 H. Lundbeck A/S i Lundbeck Ltd. przeciwko Komisji Europejskiej, "Internetowy Kwartalnik Antymonopolowy i Regulacyjny" 2016, nr 8(5), s. 127 i n.; S. Gallasch, A New Dimension to EU Pharma Antitrust Product Hopping and Unilateral Pay for Delay, „European Competition Journal” 2016, vol. 12, no. 1, s. 137 i n.; M.L. Fialkoff, Pay-for-Delay Settlements in the Wake of Actavis, "Michigan Telecommunications and Technology Law Review" 2014, vol. 20, s. 523 i n.; H. Hovenkamp, Anticompetitive Patent Settlements and the Supreme Court's Actavis Decision, "Minnesota Journal of Law, Science \&Technology" 2014, vol. 15, no. 1, s. 3 i n.; Z. Wang, Reanalyzing Reverse-Payment Settlements: A Solution to the Patentee's Dilemma, "Cornell Law Review” 2014, vol. 99, s. 1227 i n.; C.S. Hemphill, Paying for Delay: Pharmaceutical Patent Settlement as a Regulatory Design Problem, "New York University Law Review" 2006, vol. 81, s. 1560 i n.

${ }^{16}$ Zob. EU merger control and innovation. Competition policy brief, April 2016, http://ec. europa.eu/competition/publications/cpb/2016/2016_001_en.pdf (dostęp: 22 III 2017); M.L. Katz, H.A. Shelanski, Mergers and Innovation, "Antitrust Law Journal” 2007, vol. 74, no. 1, s. 1 i n.; Merger Review in Emerging High Innovation Markets, DAFFE/COMP(2002)20, OECD 2003; W.S. Comanor, F.M. Scherer, Mergers and Innovation in the Pharmaceutical Market, 26 X 2011, https://research.hks.harvard.edu/publications/getFile.aspx?Id=739 (dostęp: 22 III 2017). 
w tytule niniejszego artykułu tkwi jednak w jednostronnych (indywidualnych) praktykach przedsiębiorstw zajmujących pozycję dominująca na rynku, wprowadzających na rynek nowe produkty lub modyfikujących właściwości produktów już istniejących ${ }^{17}$. Dlatego też na tego rodzaju praktykach koncentrować się będą dalsze rozważania. Rzeczone praktyki mogą obejmować rynki produktów substytucyjnych lub komplementarnych względem produktów oferowanych przez przedsiębiorstwa innowacyjne ${ }^{18}$. Przykładem praktyki zorientowanej na produkty substytucyjne może być tzw. rozszerzanie gamy (asortymentu) chronionych patentami leków oryginalnych (np. o dodatkową postać lub drogę podania), co nie pozostaje bez konsekwencji dla konkurencji ze strony leków odtwórczych (generycznych). Z kolei przykładem praktyki zorientowanej na produkty komplementarne może być projekt interfejsu wpływający na kompatybilność komplementarnych komponentów sieci komputerowej.

Zarzuty antykonkurencyjnych innowacji pojawiają się w kontekście czterech co najmniej kategorii zachowań rynkowych, kwalifikowanych jako: (1) manipulacje systemem patentowym lub regulacyjnym; (2) modyfikacje produktu blokujące jego interoperacyjność z produktami konkurentów; (3) technologiczne wiązanie produktów; (4) zaniechanie udzielenia informacji warunkujących interoperacyjność konkurencyjnych produktów ${ }^{19}$. Zarzuty te sprowadzają się zwykle do twierdzenia, że

${ }^{17}$ F. Marcos, Innovation by Dominant Firms in Digital Markets: Damned if you Don't...But Damned if you do!, s. 8, http://media.leidenuniv.nl/legacy/francisco-marcos.pdf(dostęp: 22 III 2017).

${ }^{18}$ R. Gilbert, Holding Innovation to an Antitrust Standard, "Competition Policy International" 2007, vol. 3, no. 1, s. 48.

${ }^{19}$ R.J. Gilbert, Not Another Drug! Antitrust for Drug and Other Innovations, "Antitrust" 2015, vol. 30, no. 1, s. 70 i n. Konotacje z antykonkurencyjnymi innowacjami mogą też nasuwać tak specyficzne praktyki w sektorach nowych technologii, jak np. tzw. drapieżne inwestycje (ang. predatory investments), o których mówi się, gdy przedsiębiorstwo dominujące inwestuje w rozwój nowego produktu więcej, niż mogłoby uzyskać z jego sprzedaży na rynku konkurencyjnym, licząc na to, że po wykluczeniu z rynku konkurentów inwestycja ta zwróci się z nawiązką po wprowadzeniu cen monopolistycznych na nowy produkt (szerzej R.S. Markovits, Predatory Investments, 12 III 2004, s. 1 i n., "bepress Legal Series Working Paper" 187, http://law.bepress.com/expresso/eps/187 (dostęp: 17 III 2017); P. Areeda, D.F. Turner, op. cit., s. 718 i n.), czy też fałszywe lub wprowadzające w błąd (np. przedwczesne) zapowiedzi dotyczące wdrożenia nowego produktu (np. programu komputerowego) mające na celu zaszkodzenie już istniejącym lub bliskim ukończenia produktom konkurentów (ang. vaporware); szerzej M.A. Haan, Vaporware as a Means of Entry Deterrence, "The Journal of Industrial Economics" 2003, vol. 51, no. 3, s. 345 i n.; B.L. Bayus, S. Jain, A.G. Rao, Truth or Consequences: An Analysis of Vaporware 
przedsiębiorstwo dominujące celowo projektuje lub modyfikuje swoje produkty, aby zamknąć lub utrudnić konkurentom dostęp do rynku, np. poprzez zwiększenie kosztów zapewnienia interoperacyjności produktów konkurencyjnych z jego własnymi produktami, zmuszanie klientów do korzystania z jego produktów, pogarszanie działania produktów konkurencyjnych czy też zniechęcanie inwestorów lub dostawców do współpracy z konkurentami. Na gruncie prawa antymonopolowego tego rodzaju zachowania, naruszające zakaz nadużywania pozycji dominującej (monopolizacji rynku), kwalifikowane są najczęściej jako "drapieżne" lub „wykluczające" innowacje ${ }^{20}$. Innowacje drapieżne (ang. predatory innovations) kojarzy się zwykle z pozornie (iluzorycznie) innowacyjnymi przedsięwzięciami, mającymi na celu wyłącznie wykluczenie konkurentów z rynku (godząc w konkurencję, „innowacje” te nie znajdują żadnego racjonalnego uzasadnienia ekonomicznego), podczas gdy innowacje wykluczające (ang. exclusionary innovations) wywołują skutki antykonkurencyjne, których nie równoważą ewentualne uzasadnienia prokonkurencyjne, przy czym intencje, jakie za tego typu działaniami stoja, nie odgrywają tu decydującej roli ${ }^{21}$.

\section{Manipulacje systemem patentowym lub regulacyjnym}

Strategie patentowe i regulacyjne (ang. regulatory gaming) ${ }^{22}$, jako kategoria zbiorcza, obejmują rozmaite działania przedsiębiorstw innowacyjnych zmierzających do rozszerzenia zakresu lub też przedłużenia okresu wyłączności rynkowej ich produktów poprzez wykorzystywanie systemu patentowego lub innych regulacji w sposób wykluczający z rynku produkty konkurencyjne. Paradygmatyczne przykłady takich praktyk oferuje sektor farmaceutyczny, gdzie producenci leków inno-

and New Product Announcements, "Journal of Marketing Research" 2001, vol. 38, no. 1, s. 3 i n.; S.M. Levy, Should "Vaporware" Be an Antitrust Concern?, "The Antitrust Bulletin" 1997, vol. 42 , no. 1 , s. 33 i n.

${ }^{20}$ Zob. np. D.A. Crane, op. cit., s. 1 i n.; M.L. Montagnani, Predatory and Exclusionary Innovation: Which Legal Standard for Software Integration in the Context of the Competition versus Intellectual Property Rights Clash?, "IIC - International Review of Intellectual Property and Competition Law" 2006, vol. 37, no. 3, s. 304 i n.

${ }^{21}$ A.L. Foster, P.E. Greene, The Essentials of US Antitrust Law for Arbitration Practitioners, w: EU and US Antitrust Arbitration: A Handbook for Practitioners, vol. 2, ed. by G. Blanke, P. Landolt, Alphen aan den Rijn 2011, s. 1318; M.L. Montagnani, op. cit., s. 304 i n.

${ }^{22}$ S.L. Dogan, M.A. Lemley, Antitrust Law and Regulatory Gaming, "Texas Law Review" 2009, vol. 87, no. 4, s. 685 i n. 
wacyjnych (oryginalnych czy też referencyjnych) różnymi, nierzadko wyrafinowanymi metodami dążą do zablokowania lub opóźnienia wejścia na rynek leków odtwórczych (generycznych). Podobne strategie mogą być wykorzystywane także w innych sektorach gospodarki, m.in.: rolnym (np. przez producentów nasion i środków ochrony roślin), technologii informatycznych (np. przez producentów mikroprocesorów i oprogramowania komputerowego) czy telekomunikacyjnym (np. przez producentów urządzeń opartych na standardach telekomunikacyjnych nowych generacji $)^{23}$.

Spektrum potencjalnie antykonkurencyjnych strategii patentowych i regulacyjnych jest szerokie. Konotacje $z$ antykonkurencyjnymi innowacjami mogą budzić zwłaszcza powszechnie obserwowane (głównie w sektorze farmaceutycznym) praktyki polegające na tworzeniu tzw. klastrów patentowych (ang. patent clusters) oraz na tzw. odświeżaniu patentów (ang. evergreening) lub też specyficznym przenoszeniu popytu $\mathrm{z}$ jednego produktu na inny (ang. product hopping).

Klastry patentów powstają wskutek zgłaszania dużej liczby wynalazków odnoszących się do tego samego produktu, często wzajemnie powiązanych i opartych na podobnej myśli technicznej ${ }^{24}$. Jak wskazała Komisja Europejska w raporcie dotyczącym sektora farmaceutycznego, „pojedyncze leki są chronione nawet przez niemal 100 rodzin patentów dotyczacych jednego produktu, co może oznaczać nawet 1300 przyznanych patentów lub rozpatrywanych wniosków patentowych we wszystkich państwach członkowskich"25. Dysponowanie bogatym portfolio patentowym jest dla przedsiębiorstwa innowacyjnego korzystne z kilku co najmniej powodów i może być przejawem strategicznego (czy wręcz obstrukcjonistycznego) patentowania ${ }^{26}$. W szczególności rodzi

${ }^{23}$ R.J. Gilbert, Not Another Drug!..., s. 70; C. Lawson, Competition in the Agricultural Seeds Sector: Patents and Competition at a Cross-roads?, w: Intellectual Property and Genetically Modified Organisms: A Convergence in Laws, ed. by C. Lawson, B. Charnley, Farnham 2015, s. 86.

${ }^{24}$ Komunikat Komisji, Streszczenie sprawozdania z badania sektora farmaceutycznego (dalej: „,Komunikat Komisji”), , s. 11, http://www.europarl.europa.eu/meetdocs/2009_2014/ documents/envi/dv/200/200911/20091130_envi_pharmaceutical_inquiry_pl.pdf (dostęp: 22 III 2017); A. Jabłonowska, Opóźnianie wejścia na rynek generycznych produktów leczniczych na tle prawa patentowego oraz prawa konkurencji, Warszawa 2015, s. 48; Ż. Pacud, Ochrona patentowa zastosowań medycznych, w: Zarys Prawa Wtasności Intelektualnej. Rynek farmaceutyczny a prawo własności intelektualnej, pod red. M. Kępińskiego, Warszawa 2013, s. 31-32.

${ }^{25}$ Komunikat Komisji, s. 12.

${ }^{26}$ A. Jabłonowska, op. cit., s. 49-50. 
po stronie konkurentów stan niepewności patentowej (co do możliwości wykorzystania wynalazku), utrudnia im prowadzenie postępowań o unieważnienie licznych patentów (nawiasem mówiąc, procesy sądowe w sprawach patentowych są często długotrwałe, skomplikowane, kosztowne i o trudnym do przewidzenia wyniku) i powoduje piętrzenie płatności (ang. royalty stacking), co ostatecznie może powstrzymywać lub opóźniać wprowadzenie na rynek konkurencyjnych produktów (ergo hamować innowacyjność ${ }^{27}$.

Wielość patentów wtórnych udzielanych w różnych odstępach czasu i bazujących na określonym wynalazku pierwotnym bywa też przejawem strategii zmierzającej do "odświeżenia” patentu ${ }^{28}$. Polega ona na tym, że przedsiębiorstwo innowacyjne składa liczne zgłoszenia patentowe na chroniony już podstawowym patentem produkt, $\mathrm{z}$ wykorzystaniem jego właściwości, które nie są najważniejsze (a często są wręcz nieistotne ${ }^{29}$ ), mając nadzieję, że co najmniej jedno z tych zgłoszeń zostanie przyjęte i nie zostanie podważone w sporze sądowym. Takie działanie może nie tylko zwiększać klaster patentowy, ale nade wszystko może faktycznie wydłużyć okres gasnącej ochrony wynikającej z patentu podstawowego (ergo "odświeżyć" quasi-monopol rynkowy przedsiębiorstwa) $)^{30}$.

W ramach tzw. zarządzania cyklem życia produktu (ang. life cycle management), tj. długofalowych działań podejmowanych przez przedsiębiorstwa innowacyjne dążące do zapewnienia sobie stałego źródła przychodów ze sprzedaży kolejnych produktów, wyodrębnia się często specyficzny wariant opisanej wyżej strategii evergreeningu ("odświeżania” patentów), określany równie idiomatycznym i utrwalonym już w anglojęzycznej terminologii prawniczej i ekonomicznej mianem product hopping $^{31}$. Nawiasem mówiąc, oba te określenia traktowane są czasem jako

${ }^{27}$ Komunikat Komisji, s. 11-12; R. Stankiewicz, Model racjonalizacji dostęu do produktu leczniczego. Zagadnienia publicznoprawne, Warszawa 2014, s. 48 i n.; M. Lemley, C.M. Shapiro, Patent Holdup and Royalty Stacking, "Texas Law Review" 2007, vol. 85, s. 1991 i n.; J. Prokop, A. Karbowski, Patent Hold-Up and Royalty Stacking: The Case of Multiple Downstream Firms, "Procedia Economics and Finance” 2015, vol. 24, s. 306 i n.

${ }^{28}$ A. Jabłonowska, op. cit., s. 50.

${ }^{29}$ Media donosiły np. o przypadku opatentowania przez jednego z producentów farmaceutyków koloru butelki z lekami, co uzasadniano „wrażliwością leku na światło", zob. Fighting Generic Drugs, http://www.cbsnews.com/news/fighting-generic-drugs/ (dostęp: 22 III 2017).

${ }^{30}$ A. Jabłonowska, op. cit., s. 50.

${ }^{31}$ Termin product hopping został po raz pierwszy użyty i zdefiniowany przez H. Hovenkampa, zob. H. Hovenkamp et al., IP and Antitrust: An Analysis of Antitrust Principals Applied to Intellectual Property Law, New York 2016, § 12.05, s. 12-51 i n.; A. Devlin, 
synonimy (pierwsze preferowane jest w UE, drugie w Stanach Zjednoczonych), niemniej jednak na potrzeby niniejszej publikacji przyjęto, że mamy do czynienia z pokrewnymi, jednak nie tożsamymi zjawiskami ${ }^{32}$. Najkrócej rzecz ujmując, o ile evergreening polega na uzyskiwaniu wielu patentów na ten sam produkt, o tyle product hopping sprowadza się do zamiany sprzedawanego dotąd opatentowanego produktu (oryginalnego czy też pierwszej generacji) na nowy, również opatentowany produkt (drugiej generacji), co pozwala niejako „restartować zegar” odliczający czas prawnej wyłączności dotychczasowego produktu, w momencie gdy patent na ten produkt wygaśnie lub zostanie unieważniony ${ }^{33}$. Prima facie wprowadzanie na rynek nowej, w założeniu bardziej zaawansowanej czy też ulepszonej, wersji dotychczasowego produktu wydaje się czymś zgoła korzystnym i pożądanym. Praktyka taka może zacząć budzić wątpliwości w sytuacji, gdy nowa wersja produktu (czasem o wątpliwej z punktu widzenia nabywców przewadze nad oryginałem ${ }^{34}$ ) korzysta z silniejszej i dłuższej ochrony patentowej w porównaniu z poprzednikiem, którego ochrona patentowa ma wkrótce wygasnąćc ${ }^{35}$. $\mathrm{W}$ takich bowiem okolicznościach producent innowacyjny może być zainteresowany przeniesieniem popytu z produktu oryginalnego na nowy, np. poprzez intensywną promocję tego ostatniego, podniesienie ceny tego pierwszego, a czasem wręcz wycofanie go z rynku (to ostatnie posunięcie określa się $w$ literaturze mianem tzw. strategicznego wycofania $\left.^{36}\right)$. Modelowe przykłady tego rodzaju strategii wydłużania

Exclusionary Strategies in the Hatch - Waxman Context, "Michigan State Law Review” 2007, vol. 2007, s. 658.

${ }^{32}$ I. Vanderborre, J.K. York, M.J. Frese, "Product Hopping" on Both Sides of the Pond: A Survey of U.S. and EU Cases, "Competition Policy International Antitrust Chronicle" 2014, no. 2, s. 1 i n.; M.A. Lemley, Ignoring Patents, w: The Future of the Patent System, ed. by R. Shimanami, Cheltenham 2012, s. 84; M.A. Carrier, S.D. Shadowen, Product Hopping: A New Framework, "Notre Dame Law Review" 2016, vol. 92, no. 1, s. 171; J.R. Thomas, Patent "Evergreening": Issues in Innovation and Competition, CSR Reports for Congress, 13 XI 2009, s. 1 i n.

${ }^{33}$ M.A. Lemley, op. cit., s. 84.

${ }^{34} \mathrm{~W}$ przypadku farmaceutyków różnica między lekami pierwszej i drugiej generacji może sprowadzać się do odmiennej formy dozowania, np. kapsułkę zastępuje się tabletką; szerzej R. Feldman, E. Frondorf, Drug Wars: A New Generation of Generic Pharmaceutical Delay, "Harvard Journal on Legislation” 2016, vol. 53, s. 530-531; Roundtable on Generic Pharmaceuticals, DAF/COMP(2009)39, OECD 2010, s. 134.

${ }^{35}$ B.M. Miller, Product Hopping: Monopolization or Innovation, „Boston University Journal of Science and Technology Law" 2016, vol. 22, s. 94-95.

${ }^{36} \mathrm{~W}$ odniesieniu do rynku farmaceutycznego trafnie wskazuje się (Ż. Pacud, op. cit., s. 33; A. Jabłonowska, op. cit., s. 54-55), że wycofanie leku z obrotu jeszcze przed 
cyklu życia produktów (nawet za cenę swoistej „kanibalizacji” produktu referencyjnego) oferuje przemysł farmaceutyczny ${ }^{37}$. Jak ustaliła w przywoływanym już komunikacie Komisja Europejska, wprowadzenie przez producenta innowacyjnego leku drugiej generacji (wtórnego) bywa częścią scenariusza, który ma doprowadzić do opóźnienia wejścia na rynek pierwszego leku odtwórczego (generycznego), a tym samym ma chronić własny lek (drugiej generacji) przed konkurencją ze strony leków generycznych ${ }^{38}$. Jak to ujęła Komisja,

aby z powodzeniem wprowadzić na rynek lek drugiej generacji, producenci innowacyjni podejmują intensywne działania marketingowe $\mathrm{w}$ celu przestawienia jak największej liczby pacjentów na nowy lek przed pojawieniem się wersji generycznej produktu pierwszej generacji. Jeżeli im się to uda, prawdopodobieństwo, że producenci leków generycznych zdobędą istotny udział w rynku, znacznie spada. Jeżeli jednak leki generyczne wejdą na rynek, zanim uda się przestawić pacjentów, producent innowacyjny może mieć trudności z przekonaniem lekarzy do przepisywania produktu drugiej generacji lub z uzyskaniem wysokiej ceny za produkt drugiej generacji ${ }^{39}$.

W szczególnych okolicznościach (np. gdy nie jest możliwe wykorzystywanie luk w systemie regulacyjnym) jednostronne praktyki

wygaśnięciem jego ochrony patentowej może wydawać się niekorzystne dla dysponenta patentu, gdyż pozbawia go zysków ze sprzedaży wciąż chronionego produktu, jednak w dłuższej perspektywie może okazać się niezwykle intratne, jeśli towarzyszy temu posunięciu wprowadzenie na rynek ulepszonego następcy, który zdobywa znaczny udział w rynku. Farmaceutyk wycofany z rynku jawi się jako przestarzały, mniej skuteczny lub potencjalnie bardziej szkodliwy. W konsekwencji ponowne wprowadzenie jego generycznej wersji (po wygaśnięciu ochrony patentowej oryginału) może okazać się wysoce problematyczne.

${ }^{37}$ M.A. Carrier, S.D. Shadowen, op. cit., s. 167 i n.; S. Hemphill, Generic Pharmaceuticals, DAF/COMP/WD(2014)76, OECD 2014, s. 7 i n.; R. Feldman, E. Frondorf, op. cit., s. 527 i n.; V. Iyengar, Should Pharmaceutical Product Hopping Be Subject to Antitrust Scrutiny?, "Journal of the Patent and Trademark Office Society" 2015, vol. 97, s. 663 i n.; V. Iyengar, Mylan v. Warner Chilcott: A Study in Pharmaceutical Product Hopping, "Marquette Intellectual Property Law Review" 2015, vol. 19, no. 2, s. 245 i n.; I. Vanderborre, J.K. York, M.J. Frese, op. cit., s. 1 i n.; M.S. Royall, A.E. Johnson, J.C. McKenney, Antitrust Scrutiny of Pharmaceutical "Product Hopping", "Antitrust" 2013, vol. 28, no. 1, s. 71 i n.; R.J. Gilbert, Not Another Drug!..., s. 71 i n.; A. Lamote, P. L'Ecluse, C. Longeval, Generic Entry - A Challenge to Traditional EC Competition Law?, "Life Sciences” 2008, no. 9, s. 81 i n.; M.L. Ethier, Permissible Product Hopping: Why a Per Se Legal Rule Barring Antitrust Liability is Necessary to Protect Future Innovation in the Pharmaceutical Industry, "Akron Intellectual Property Journal" 2009, vol. 3, s. 323 i n.; J. Cheng, An Antitrust Analysis of Product Hopping in the Pharmaceutical Industry, "Columbia Law Review" 2008, vol. 108, s. 1471 i n.

${ }^{38}$ Komunikat Komisji, s. 16.

${ }^{39}$ Ibidem, s. 17. 
ograniczające konkurencję $\mathrm{w}$ ramach strategii określanej jako product hopping (czy ogólniej - w ramach zarządzania cyklem życia produktu) mogą być stosowane $\mathrm{z}$ wykorzystaniem ugód typu pay for delay. Na mocy tego rodzaju ugody producent produktu innowacyjnego, któremu wygasa ochrona patentowa, płaci konkurencyjnemu producentowi produktu odtwórczego, którego wejście na ten sam rynek jest spodziewane najwcześniej, aby było ono opóźnione ${ }^{40}$. W ten sposób producent innowacyjny zyskuje (kupuje) czas niezbędny do przestawienia nabywców (przeniesienia popytu) z produktu oryginalnego na produkt drugiej generacji (już po wygaśnięciu patentu na produkt innowacyjny) ${ }^{41}$.

W ramach aktywnej strategii patentowej formalnym (standardowym) sposobem na przedłużenie ochrony wynikającej z patentu może być uzyskanie dodatkowego świadectwa ochronnego (ang. supplementary protection certificate, SPC) ${ }^{42}$, co eo ipso nie grozi jeszcze naruszeniem reguł konkurencji, niemniej jednak może być przejawem nadużycia pozycji dominującej przez przedsiębiorstwo zajmujące taką pozycję na rynku ${ }^{43}$. Podobnie rzecz ma się z sądowym egzekwowaniem praw z patentu, które $\mathrm{z}$ jednej strony stanowi emanację jednego z praw podstawowych, a także gwarancję przestrzegania patentów, a z drugiej - jak przyznała m.in. Komisja - może być symptomem motywowanego złą wolą nadużycia procesowego pozycji dominującej (formą "dokuczliwego procesowania się" - ang. vexatious lub sham litigation), kwalifikowanego jako drapieżna praktyka wykluczająca o charakterze pozacenowym, mająca na celu głównie, bądź nawet jedynie, eliminację lub dyscyplinowanie

${ }^{40} \mathrm{~W}$ sprawie tego rodzaju porozumień zob. prace powoływane w przypisie 15 niniejszego opracowania.

${ }^{41}$ S. Gallasch, op. cit., s. 150 i n.

${ }^{42}$ Dodatkowe świadectwo ochronne wydawane w państwach UE dla produktów leczniczych oraz środków ochrony roślin jest szczególnym instrumentem ochrony własności przemysłowej, który znajduje zastosowanie po wygaśnięciu patentu podstawowego chroniącego dany wynalazek. Wprowadzono je dlatego, że powyższe produkty przed wprowadzeniem na rynek muszą przejść odpowiednie testy i uzyskać zezwolenie na wprowadzenie do obrotu, wskutek czego efektywna ochrona patentowa i efektywne korzystanie z wynalazku ulega skróceniu. Szerzej zob. Rozporządzenie Parlamentu Europejskiego i Rady (WE) nr 469/2009 z dnia 6 V 2009 r. dotyczące dodatkowego świadectwa ochronnego dla produktów leczniczych (Dz.Urz. UE L 152 z 16 VI 2009 r., s. 1); rozdział $5^{1}$ Ustawy z dnia 30 VI 2000 r. Prawo własności przemysłowej (Dz.U. z 2013 r., poz. 1410 ze zm.); K. Klafkowska-Waśniowska, R. Sikorski, Przedmiotowe granice ochrony przyznanej dodatkowym świadectwem ochronnym (SPC), w: Zarys Prawa Własności Intelektualnej..., s. 37 i n.; G. Lachowicz, Dodatkowe świadectwo ochronne dla produktów medycznych i ochrony roślin, "Nowator" 1998, nr 7.

${ }^{43}$ A. Lamote, P. L'Ecluse, C. Longeval, op. cit., s. 81. 
konkurentów, przysporzenie im dodatkowych kosztów, bądź też odstraszenie potencjalnych konkurentów od wejścia na dany rynek albo opóźnienie tego wejścia ${ }^{44}$.

Orzecznictwo sądowe i praktyka decyzyjna organów antymonopolowych w przedmiocie manipulacji systemem patentowym lub regulacyjnym (odświeżania patentów lub przenoszenia popytu z jednego produktu na inny) pozostaje wciąż in statu nascendi. Za najbardziej doniosłe w tym względzie uznać należy rozstrzygnięcia zapadłe w dwóch wiodaccych systemach ochrony konkurencji, tj. amerykańskim - w sprawie Actavis ${ }^{45}$, oraz unijnym - w sprawie AstraZeneca ${ }^{46}$. W sprawie Actavis wyrok Sądu Apelacyjnego USA dla Drugiego Okręgu (dalej: Sąd Apelacyjny w Nowym Jorku) "wprowadził [praktykę określaną tam jako] product hopping do panteonu przestępstw antymonopolowych"47, w bezprecedensowy sposób nakazując koncernowi farmaceutycznemu kontynuowanie sprzedaży oryginalnego leku pierwszej generacji, na warunkach ustalonych w zaskarżonym wyroku Sądu Dystryktowego USA dla Południowego Dystryktu Nowego Jorku ${ }^{48}$ (do czasu pojawienia się na rynku konkurencyjnego leku generycznego), którą to sprzedażą koncern nie był zainteresowany. W sprawie tej Sąd Apelacyjny w Nowym Jorku przyjął, że zaprzestanie sprzedaży starszej wersji produktu oryginalnego może być uznane za wystarczająco "przymusowy” środek oddziaływania, uzasadniający powództwo o jego zaniechanie, nawet

\footnotetext{
${ }^{44}$ Komunikat Komisji, s. 12-13; R. Stankiewicz, op. cit., s. 58; Ż. Pacud, op. cit., s. 32; A. Jabłonowska, op. cit., s. 59 i n.; S. Dudzik, Procesowe nadużycie prawa jako przesłanka naruszenia art. 102 TFUE, „Europejski Przegląd Sądowy” 2013, nr 1, s. 18 i n.; S. Vezzoso, Towards an EU Doctrine of Anticompetitive IP-Related Litigation, "Journal of European Competition Law \& Practice" 2012, vol. 3, no. 6, s. 521 i n.; G. Myers, Litigation as a Predatory Practice, „Kentucky Law Journal” 1991-1992, vol. 80, s. 565 i n.

${ }^{45}$ New York ex rel. Schneiderman v. Actavis PLC, 787 F.3d 638 (2d Cir. 2015) (dalej: „wyrok w sprawie Actavis").

${ }^{46}$ Decyzja KE z 15 VI 2005 r. w sprawie postępowania na mocy art. 82 traktatu WE oraz art. 54 porozumienia EOG (sprawa COMP/A.37.507/F3 - AstraZeneca) (dalej: „decyzja w sprawie AZ”), Dz.Urz. UE L 332 z 30 XI 2006 r., s. 24; decyzja w pełnej wersji dostępna pod adresem: http://ec.europa.eu/competition/antitrust/cases/ dec_docs/37507/37507_193_6.pdf (dostęp: 22 III 2017); wyrok Sądu z 1 VII 2010 r. w sprawie T-321/05, AstraZeneca AB i AstraZeneca plc v. Komisja Europejska (dalej: „wyrok Sądu w sprawie AZ"), Zb. Orz. 2010, s. II-2805; wyrok Trybunału Sprawiedliwości (TS) z 6 XII 2012 r. w sprawie C-457/10 P, AstraZeneca AB i AstraZeneca plc v. Komisja Europejska (dalej: „wyrok TS w sprawie AZ”), ECLI:EU:C:2012:770.

${ }^{47}$ B. Sudol, New York v. Actavis: Innovation by Persuasion in a Noncoercive Consumer Economy, "California Law Review" 2016, vol. 7, s. 44.

${ }^{48}$ New York v. Actavis PLC, No. 14 Civ. 7473 (S.D.N.Y. Dec. 11, 2014).
} 
jeśli nie towarzyszą temu inne działania producenta tego produktu utrudniające wejście na rynek konkurencyjnego produktu odtwórczego. Zajmując takie stanowisko, sąd wprowadził wyraźną dystynkcję między dwiema formami przeniesienia popytu z produktu poprzedniej generacji na produkt nowej generacji: „miękką" - z utrzymaniem na rynku poprzedniego produktu, i "twardą" - z jego wycofaniem z rynku, uznając to ostatnie rozwiązanie za bardziej podatne na roszczenia antymonopolowe niż pierwsze. W rozpatrywanej sprawie koncern Actavis, producent leku Namenda IR, poprzez swoją spółkę zależną Forest Laboratories wprowadził na rynek nową wersję tego leku na około rok przed spodziewanym wejściem na rynek jego generycznego odpowiednika. Lek w nowej wersji - Namenda XR - przyjmowany jest raz dziennie, podczas gdy Namenda IR - dwa razy dziennie. Kiedy okazało się, że wielu lekarzy odmówiło przejścia na nowy lek (nie chcąc zaburzać utrwalonych nawyków swoich pacjentów cierpiących na chorobę Alzheimera), Actavis podjął kroki zmierzające do przymusowej zamiany leków, drastycznie ograniczając dostawy leku Namenda IR, zarazem zapowiadając jego definitywne wycofanie z rynku. Co godne odnotowania, Sąd Apelacyjny w Nowym Jorku nie podzielił argumentu Actavis, że obarczenie jej odpowiedzialnością antymonopolową wpłynie negatywnie na innowacyjność, wskazując na brak danych empirycznych na poparcie tego twierdzenia. Sąd przychylił się natomiast do argumentacji zawartej w przedłożonych opiniach "przyjaciół sądu” (łac. amici curiae), wspierających stronę powodową i podnoszących, że przyznanie immunitetu antymonopolowego praktykom strony pozwanej (kwalifikowanych jako product hopping) „może szkodzić prawdziwej innowacyjności poprzez zachęcanie producentów farmaceutyków do koncentrowania się na przenoszeniu popytu na trywialne lub pomniejsze modyfikacje produktowe zamiast inwestowaniu w badania i rozwój niezbędne do rozwijania bardziej ryzykownych, ale medycznie znaczących innowacji" ${ }^{49}$. Konkludując analizę kwestionowanych praktyk Actavis pod kątem przysparzanych przez nie prokonkurencyjnych korzyści i antykonkurencyjnych szkód, Sąd Apelacyjny w Nowym Jorku stwierdził, że „kombinacja wycofania z rynku skutecznego leku i wprowadzenie jego przeformułowanej wersji, co miało dwojaki skutek w postaci wymuszenia na pacjentach przejścia na nową wersję oraz uniemożliwienia konkurencji leków generycznych, bez uprawnionego uzasadnienia ekonomicznego, stanowi naruszenie

\footnotetext{
${ }^{49}$ Wyrok w sprawie Actavis, s. 50.
} 
$\S 2$ ustawy Shermana" ${ }^{\prime 50}$. Komentowany wyrok odzwierciedla wyrażany wcześniej przez prominentnych przedstawicieli doktryny pogląd, że „product hopping [w wykonaniu producentów leków oryginalnych] uskuteczniany, by nie dopuścić do konkurencji producentów generycznych, jest właśnie takim typem zachowania, które ustawa Shermana potępia. Co prawda, monopoliści nie mają ogólnego obowiązku pomagania konkurentom, niemniej jednak ciąży na nich obowiązek powstrzymywania się od zachowań, które nie mają innego celu lub skutku niż wykluczenie konkurencji [wyróżnienie R.M.]"51.

Z kolei w precedensowej sprawie AstraZeneca (AZ) Komisja Europejska po raz pierwszy za sprzeczne z regułami konkurencji nadużycie pozycji dominującej uznała nadużycie procedur regulacyjnych. Komisja zarzuciła temu koncernowi farmaceutycznemu dwukrotne naruszenie zakazu nadużywania pozycji dominującej z art. 82 Traktatu ustanawiającego Wspólnotę Europejską ${ }^{52}$ (TWE) (obecnie art. 102 Traktatu o funkcjonowaniu UE ${ }^{53}$, TFUE). Pierwsze nadużycie polegało na złożeniu szeregu celowo wprowadzających w błąd oświadczeń przed urzędami patentowymi oraz sądami krajowymi niektórych państw członkowskich, co stanowiło część ogólnej strategii mającej na celu powstrzymanie konkurencji ze strony wytwórców produktów generycznych dzięki uzyskaniu nowych lub utrzymaniu w mocy świadectw ochronnych (SPC) na substancję aktywną leku Losec, do których AZ nie miała prawa lub do których miała prawo, ale na krótszy okres ${ }^{54}$. Druga z zakwestionowanych praktyk polegała na zastąpieniu leku Losec w kapsułkach nową jego postacią $\mathrm{w}$ formie tabletek i jednoczesnym wycofaniu w kilku państwach członkowskich pozwoleń na obrót preparatem w tradycyjnej formie $\mathrm{e}^{55}$. Zabieg ten uniemożliwił producentom generycznym skorzystanie ze skróconej procedury dopuszczenia odtwórczych odpowiedników Losecu do obrotu, co przyczyniło się do opóźnienia ich wejścia na

\footnotetext{
${ }^{50}$ Ibidem.

${ }^{51}$ H. Hovenkamp et al., op. cit., § 15.03[B], s. 15-79. Szerzej o komentowanym wyroku (także krytycznie): J.M. Shepherd, Deterring Innovation: New York v. Actavis and the Duty to Subsidize Competitors' Market Theory, "Minnesota Journal of Law, Science \& Technology" 2016, vol. 17, no. 2, s. 663 i n.; B. Sudol, op. cit., s. 38 i n.

${ }^{52}$ Wersja skonsolidowana Traktatu ustanawiającego Wspólnotę Europejską (Dz.Urz. UE C 321E z 29 XII 2006 r., s. 1).

${ }^{53}$ Traktat o funkcjonowaniu Unii Europejskiej - wersja skonsolidowana (Dz.Urz. UE C 202 z 7 VI 2016 r., s. 47).

${ }^{54}$ Motywy 143-254 decyzji w sprawie AZ.

${ }^{55}$ Motywy 255-323 decyzji w sprawie AZ.
} 
rynek, a tym samym osłabienia konkurencji. Stanowisko Komisji uznające wskazane praktyki AZ za antykonkurencyjne nadużycie procedur regulacyjnych zostało $\mathrm{w}$ przeważającej części podtrzymane zarówno przez Sąd, jak i przez TS. Co warte podkreślenia, w kontekście zarzutu o systematyczne nadużywanie przez AZ prawa farmaceutycznego Sąd wskazał, że na przedsiębiorstwie zajmującym pozycję dominująca spoczywa szczególna odpowiedzialność, by swoim zachowaniem nie naruszać skutecznej i niezakłóconej konkurencji poprzez stosowanie środków innych niż mieszczące się w ramach konkurencji merytorycznej (czyli takiej, która oparta jest głównie na jakości świadczeń) ${ }^{56}$. Chociaż zajmowanie przez przedsiębiorstwo pozycji dominującej nie pozbawia go prawa do ochrony własnych interesów handlowych, gdy są one zagrożone, nie może ono korzystać z procedur prawnych $\mathrm{w}$ taki sposób, by uniemożliwić lub utrudnić wejście na rynek konkurentów, chyba że działania te, mieszczące się $\mathrm{w}$ ramach konkurencji merytorycznej, służą ochronie uprawnionych interesów przedsiębiorstwa, bądź też są obiektywnie uzasadnione ${ }^{57}$. Nadużyciem tego rodzaju były zakwestionowane praktyki AZ, za którymi, jak ocenił Sąd, nie stały żadne względy obiektywnej natury, poza chęcią utrudnienia rejestracji generycznych odpowiedników jej własnego preparatu. Zarazem jednak Sąd wyraźnie stwierdził, że zgodne z prawem i mieszczące się w zakresie normalnych zachowań konkurencyjnych jest opracowanie przez przedsiębiorstwo, nawet zajmujące pozycję dominująca, strategii mającej na celu zminimalizowanie erozji jego sprzedaży i stawienie czoła konkurencji produktów generycznych, poprzez wycofanie z rynku leku pierwszej generacji (kapsułek Losecu) i wprowadzenie jego nowej wersji (leku drugiej generacji - tabletek Losecu) ${ }^{58}$. Nadużyciem było natomiast cofnięcie zezwoleń na obrót lekiem pierwszej generacji (kapsułkami Losecu) w połączeniu z zastąpieniem sprzedaży tego leku (czyli jego wycofaniem z rynku) i wprowadzeniem na rynek leku drugiej generacji ${ }^{59}$.

${ }^{56}$ Wyrok Sądu w sprawie AZ, pkt 671. Notabene w polskim tłumaczeniu wyroku określenie "competition on the merits" przetłumaczono nietrafnie jako "konkurencja niecenowa", zamiast "konkurencja merytoryczna"; w tej kwestii zob. np. What is Competition on the Merits?, OECD Policy Brief, June 2006, http://www.oecd.org/competition/ mergers/37082099.pdf (dostęp: 22 III 2017).

${ }^{57}$ Wyrok Sądu w sprawie AZ, pkt 672.

${ }^{58}$ Wyrok Sądu w sprawie AZ, pkt 804, 808 i 811.

${ }^{59}$ Wyrok Sądu w sprawie AZ, pkt 806, 807 i 811. Szerzej o sprawie AZ zob. D. Kostecka-Jurczyk, Glosa do wyroku Sądu Generalnego z dnia 1 lipca 2010 r. w sprawie T-321/05 


\section{Modyfikacje produktu blokujące jego interoperacyjność z produktami konkurentów}

W epoce cyfrowej interoperacyjnośćc ${ }^{60}$ stała się rychło technicznym i biznesowym imperatywem zarówno przedsiębiorstw, jak i władz publicznych $^{61}$. Wprawdzie nie jest ona wartością samą $w$ sobie, ale $z$ reguły (choć nie zawsze) przyczynia się do wzrostu innowacyjności, konkurencji oraz dobrobytu konsumentów. $Z$ tego też powodu promowanie interoperacyjności uznaje się za uzasadnione (gdy przysparza ona korzyści publicznych) ${ }^{62}$. Jednakże z perspektywy poszczególnych przedsiębiorstw konkurujących na rynku nieograniczona interoperacyjność nie zawsze jest osiągalna lub pożądana. Może być ona kosztowna i trudna do osiągnięcia zwłaszcza wtedy, gdy produkt, którego dotyczy, musi współdziałać $\mathrm{z}$ wieloma innymi produktami ${ }^{63}$. Poza tym w pewnych okolicznościach dopuszczenie możliwości limitowania

AstraZeneca przeciwko Komisji Europejskiej, „Acta Universitatis Wratislaviensis” 2013, t. CCCXV/1, nr 3508, s. 345 i n.; T. Kozieł, Glosa do wyroku S(PI) z dnia 1 lipca 2010 r., T-321/05, "Europejski Przegląd Sądowy” 2011, nr 7, s. 40 i n.; D.W. Hull, The AstraZeneca Judgment: Implications for IP and Regulatory Strategies, "Journal of European Competition Law \& Practice" 2010, vol. 6, no. 1, s. 500 i n.; N. Fagerlund, S.B. Rasmussen, AstraZeneca: The First Abuse Case in the Pharmaceutical Sector, "Competition Policy Newsletter" 2005, no. 3 , s. 54 i n.

${ }^{60}$ Interoperacyjność, kojarzona zwykle z systemami informatycznymi, jest różnie rozumiana, zależnie od kontekstu. Wedle jednej z powszechnie stosowanych ogólnych definicji interoperacyjności oznacza ona zdolność systemu lub produktu do współdziałania z innymi systemami lub produktami niewymagającą specjalnego wysiłku użytkownika, zob. IEEE Standards Glossary, https://www.ieee.org/education_careers/ education/standards/standards_glossary.html (dostęp: 22 III 2017). Dostrzegając priorytetowe znaczenie interoperacyjności w rozwoju administracji elektronicznej w wymiarze transgranicznym, w pierwszej wersji dokumentu Komisji Europejskiej pt. European Interoperability Framework for Pan-European eGovernment Services. Version 1.0, http://ec.europa.eu/idabc/servlets/Docd552.pdf?id=19529 (dostęp: 22 III 2017), interoperacyjność zdefiniowano jako „zdolność do wymiany danych i dzielenia się informacjami i wiedzą między systemami technologii informacyjnych i komunikacyjnych (ICT), a także procesami gospodarczymi, które są przez nie wspierane" (pkt 1.1.2).

${ }^{61}$ N.L. Tsilas, The Perils of Imposing Compulsory IP Licensing to Achieve Interoperability, „The Metropolitan Corporate Counsel”, October 2005, s. 7.

${ }^{62}$ U. Gasser, J. Palfrey, Breaking Down Digital Barriers: When and How ICT Interoperability Drives Innovation, „Berkman Center Publication Series” 2007, s. 12 i n., https://dash. harvard.edu/bitstream/handle/1/2710237/Breaking Down Digital Barriers.pdf?sequence=2 (dostęp: 22 III 2017); A.K. Perzanowski, Rethinking Anticircumvention's Interoperability Policy, "University of California Davis Law Review” 2009, vol. 42, no. 9, s. 1557 i n.

${ }^{63}$ S. Van Arsdale, C. Venzke, Predatory Innovation in Software Markets, "Harvard Journal of Law \& Technology" 2015, vol. 29, no. 1, s. 246. 
interoperacyjności, czy to poprzez ograniczenia techniczne (np. manipulowanie zależnościami względem innych produktów), czy prawne (np. egzekwowanie praw własności intelektualnej), może pobudzać innowacje i postęp technologiczny ${ }^{64}$. Wymagana prawnie interoperacyjność może z kolei ograniczać innowacje. Jeśli podmioty wchodzące na rynek $z$ nowymi produktami nie mogłyby zapobiec interoperacyjności z nimi innych produktów, czy też wykorzystywaniu przez nie tych samych danych, wówczas nabywcy mogliby przenieść popyt na konkurencyjne produkty, pozbawiając tym samym pioniera (pierwszego oferenta na rynku) należnych mu potencjalnych korzyści ${ }^{65}$. Jednakże w przypadku przedsiębiorstw zajmujących pozycję dominującą na rynku, zwłaszcza w branżach tzw. nowej gospodarki ${ }^{66}$ (np. oprogramowania i usług informatycznych), charakteryzujących się efektami sieci ${ }^{67}$, modyfikacja produktu (zapewniającego tę dominację) w taki sposób, że skutkuje to blokadą (eliminacją lub ograniczeniem) jego interoperacyjności z innymi produktami (oferowanymi przez konkurentów), może stać się już problematycznym zagrożeniem dla konkurencji ${ }^{68}$. Źródłem tego problemu może być nie tyle techniczna przewaga

${ }^{64}$ Ibidem.

${ }^{65}$ Ibidem; zob. też U. Gasser, J. Palfrey, op. cit., s. 17-18.

${ }^{66}$ Termin „nowa gospodarka” (używany zamiennie z terminami: „gospodarka oparta na wiedzy", "gospodarka cyfrowa" czy "gospodarka sieciowa") oznacza, wedle jednej z wielu jego definicji, gospodarkę opartą "na coraz większym udziale wiedzy i informacji w osiąganiu celu gospodarczego, co znajduje odzwierciedlenie w rozwoju opartych na wiedzy technologii (w szczególności ICT) oraz ich ekspansji we wszystkie dziedziny gospodarowania, przyczyniając się na zasadzie sprzężenia zwrotnego z postępującą globalizacją do modyfikacji dotychczas obowiązujących prawidłowości ekonomicznych" (R. Żelazny, Nowa gospodarka: mity i rzeczywistość. Od fascynacji do naukowego poznania, w: Problemy globalizacji gospodarki, pod red. T. Bernata, Szczecin 2003, s. 88.

${ }^{67}$ Efekt sieciowy (efekt ekonomii skali konsumpcji) polega na tym, że wartość dobra wzrasta proporcjonalnie do liczby jego użytkowników. W konsekwencji, jeżeli wykazujący taką cechę produkt zacznie dominować na rynku, to popyt na podobne produkty załamie się, co sprzyja monopolizacji rynku. Efekty sieciowe, znane wcześniej np. w takich gałęziach, jak transport czy telekomunikacja, szczególnego znaczenia nabrały w dobie rozwoju technik teleinformatycznych, opanowując nowe obszary, m.in. rynek sprzętu i oprogramowania komputerowego oraz usługi internetowe, a ogólnie - gałęzie gospodarki oparte na wiedzy; zob. R. Kowalski, Efekty sieciowe a błędy rynku, w: Problemy globalizacji..., s. 115 i n.; N. Economides, Antitrust Issues in Network Industries, w: The Reform of EC Competition Law, ed. by I. Kokkoris, I. Lianos, Alphen aan den Rijn 2009, s. 343 i n.; C. Shapiro, Exclusivity in Network Industries, "George Mason Law Review" 1999, no. 7, s. 673 i n.; M.A. Lemley, D. McGowan, Legal Implications of Network Economic Effects, "California Law Review" 1998, vol. 86, s. 481 i n.

${ }^{68}$ S. Van Arsdale, C. Venzke, op. cit., s. 247; M.A. Lemley, D. McGowan, op. cit., s. 497. 
dominującego produktu, co jego popularność (powszechność). Przykładowo, wartość platform mediów społecznościowych czy też oprogramowania, których kluczowymi atrybutami są współdziałanie użytkowników i efekty sieciowe, w dużej mierze zależy od liczby użytkowników. Okoliczność ta stwarza dominantom rynkowym okazję do osiagania partykularnych korzyści w wyniku zablokowania interoperacyjności dominującego produktu, jako że posunięcie to może okazać się nader dotkliwe dla mniejszych (konkurencyjnych) sieci ${ }^{69}$. Analiza orzecznictwa antymonopolowego dowodzi, że zagrożenie dla konkurencji z powodu modyfikacji produktów (np. w formie aktualizacji programów komputerowych), blokujących ich interoperacyjność z produktami konkurentów, nie jest jedynie teoretyczne. Przykładowo, w Stanach Zjednoczonych za naruszające zakaz monopolizacji z \& 2 ustawy Shermana uznano praktyki spółki Microsoft, polegające na modyfikacji systemu operacyjnego Windows oraz przeglądarki Internet Explorer w sposób blokujący interoperacyjność z tym systemem konkurencyjnych przeglądarek (zwłaszcza Netscape Navigator) ${ }^{70}$. Orzekający w tej sprawie Sąd Apelacyjny USA dla Okręgu Dystryktu Kolumbii (dalej: Sąd Apelacyjny w Waszyngtonie) podniósł m.in., że "co do zasady, sądy słusznie podchodzą sceptycznie do zarzutów o szkodzenie konkurencji przez dominujące przedsiębiorstwo, modyfikujące swój produkt [...]. $\mathrm{Na}$ konkurencyjnym rynku, przedsiębiorstwa rutynowo inwestują w innowacje z zamiarem pozyskania klientów, niekiedy wprowadzając produkty niekompatybilne z produktami oferowanymi przez konkurentów; pociąganie do odpowiedzialności monopolisty, który postępuje tak samo, nieuchronnie ograniczałoby w jakimś stopniu innowacyjność"71. Zarazem jednak (w tym samym akapicie) sąd wyraźnie podkreślił, iż "sądowe poszanowanie innowacyjności produktowej [...] nie oznacza, że decyzje monopolisty dotyczące konstrukcji produktów [w tym ich modyfikacji - dop. R.M.] są per se legalne". Nie negując wyjątkowej rangi sprawy Microsoft, warto odnotować, że nie był to pierwszy przypadek uznania przez amerykańskie władze antymonopolowe i sądy, iż określone modyfikacje produktowe naruszają reguły konkurencji. Dość wspomnieć tu o wyrokach sądowych w sprawie Bard ${ }^{72}$, w której za przejaw monopolistycznego nadużycia uznano modyfikację

\footnotetext{
${ }^{69}$ S. Van Arsdale, C. Venzke, op. cit., s. 247.

${ }^{70}$ Zob. wyrok w sprawie United States v. Microsoft Corp., 253 F.3d 34 (D.C. Cir. 2001).

${ }^{71}$ Wyrok w sprawie United States v. Microsoft Corp., 253 F.3d 65 (D.C. Cir. 2001).

${ }^{72}$ C.R. Bard, Inc. v. M3 Systems, Inc., 157 F.3d 1340 (30 IX 1998).
} 
konstrukcji opatentowanego urządzenia do wykonywania zabiegów biopsji w taki sposób, że uniemożliwiało to korzystanie $\mathrm{z}$ igieł produkowanych przez innego dostawcę, a także o ugodzie Federalnej Komisji Handlu z koncernem Intel ${ }^{73}$, zawartej w następstwie zakwestionowania jego praktyk polegających m.in. na takiej modyfikacji konstrukcji układów scalonych, która skutkowała sztucznym (nieuzasadnionym) zaniżaniem wydajności technologii i produktów dostarczanych przez konkurentów, lub wręcz blokowaniem interoperacyjności tych produktów. Przyznać jednak trzeba, że granica między prawdziwie innowacyjnymi modyfikacjami produktów, będącymi przejawem konkurencji merytorycznej, a tylko pozornie innowacyjnymi modyfikacjami, mającymi na celu zablokowanie interoperacyjności i przez to wykluczenie z rynku konkurencyjnych produktów, bywa subtelna, co utrudnia antymonopolową kwalifikację tego rodzaju praktyk i powoduje, że bywa ona chwiejna. Egzemplifikacją tego stanu rzeczy mogą być postępowania antymonopolowe prowadzone przeciwko spółce Apple. W 2003 r. wdrożyła ona program FairPlay do zarządzania prawami cyfrowymi DRM (ang. digital rights management), którego deklarowanym celem było zapobieganie nielegalnemu używaniu cyfrowych plików muzycznych sprzedawanych w jej internetowym sklepie iTunes Music Store. Zabezpieczenia te nie okazały się remedium na problem piractwa (co przyznał sam Steve Jobs), skutkowały natomiast tym, że pliki muzyczne oferowane w sklepie iTunes można było odtwarzać jedynie w urządzeniach iPod produkowanych przez Apple, w których z kolei nie można było odtwarzać plików pochodzących od jej konkurentów. W reakcji na stworzenie tego swoistego, zamkniętego „ekosystemu” produktowego w kilku krajach europejskich ( w tym w Danii, Finlandii, Norwegii, Szwecji, Niemczech i Francji) wszczęto publiczne postępowania antymonopolowe lub konsumenckie, a w Stanach Zjednoczonych wniesiono prywatny, zbiorowy pozew antymonopolowy, zarzucając Apple zakazaną monopolizację rynku cyfrowych nagrań muzycznych, co w konsekwencji skłoniło spółkę do zaprzestania w 2009 r. sprzedaży plików muzycznych obwarowanych restrykcjami DRM ${ }^{74}$. Co jednak szczegól-

${ }^{73}$ Decision and Order, Intel Corp., No. 9341 (F.T.C. 2010).

${ }^{74}$ Zob. The Digital Economy, DAF/COMP(2011)16, OECD 2011, s. 5; A.K. Perzanowski, op. cit., s. 1598 i n.; M. Valimaki, V. Oksanen, DRM Interoperability and Intellectual Property Policy in Europe, "European Intellectual Property Review" 2006, vol. 26, no. 11, s. 562 i n.; D. Sobel, A Bite out of Apple - iTunes, Interoperability, and France's Dadvsi Law, "Berkeley Technology Law Journal" 2007, vol. 22, no. 1, s. 267 i n. 
nie warte odnotowania, oddalając w 2014 r. wzmiankowane powództwo przeciwko Apple, Sąd Dystryktowy USA dla Północnego Dystryktu Kalifornii (dalej: Sąd Dystryktowy w Oakland) orzekł, że wprowadzane przez nią modyfikacje konfiguracji sprzętowej oraz oprogramowania nie stanowiły naruszenia amerykańskiego prawa antymonopolowego ${ }^{75}$. Rozstrzygnięcie to sprowadzało się do odpowiedzi na pytanie, czy - jak utrzymywała strona powodowa - wdrażając kolejne aktualizacje programu iTunes (7.0 i 7.4), blokujące wprowadzoną przez konkurencyjny serwis muzyczny RealNetworks technologię Harmony, umożliwiającą obejście DRM i tym samym odtwarzanie oferowanej przezeń muzyki na iPodzie, spółka Apple celowo wykluczała z rynku konkurentów (zwłaszcza RealNetworks), nielegalnie monopolizując rynek cyfrowych plików muzycznych, czy - jak z kolei twierdziła strona pozwana - rzeczone modyfikacje miały jedynie na celu udoskonalenie jej produktu i poprawę jego użytkowania, w szczególności poprzez umożliwienie odtwarzania na urządzeniach iPod plików wideo, wyświetlanie okładek albumów muzycznych oraz zwiększenie bezpieczeństwa programu. Innymi słowy, odpowiedzi wymagało pytanie, czy modyfikacje oprogramowania iTunes zainstalowanego w iPodach były "rzeczywistym udoskonaleniem produktu" (ang. genuine product improvement). Na pytanie to Sąd Dystryktowy w Oakland odpowiedział twierdząco, unikając tym samym konieczności wyważania (konfrontowania) możliwych ulepszeń produktu oraz towarzyszących im ograniczeń konkurencji. Wedle tego stanowiska sądu, będącego kontynuacją linii orzeczniczej przyjętej w kilku innych wyrokach sądów amerykańskich ${ }^{76}$, w przypadku jakiegokolwiek rzeczywistego ulepszenia produktu nie jest możliwe kwalifikowanie go jako naruszającej amerykańskie prawo antymonopolowe praktyki antykonkurencyjnej, nawet jeśli ulepszenie to skutkuje blokadą interoperacyjności niektórych innych (konkurencyjnych) produktów ${ }^{77}$.

${ }^{75}$ In re Apple iPod iTunes Antitrust Litigation, No. 05-CV-0037 (N.D. Cal. 16 XII 2014).

${ }^{76}$ Zwłaszcza Allied Orthopedic Appliances Inc. v. Tyco Health Care Group LP, 592 F.3d 991 (9th Cir. 2010) oraz Foremost Pro Color, Inc. v. Eastman Kodak Co., 703 F.2d 534, 545 (9th Cir. 1983).

77 Szerzej: J.M. Newman, Anticompetitive Product Design in the New Economy, "Florida State University Law Review" 2012, vol. 39, no. 3, s. 681 i n.; M.L. Popofsky, Product Redesign and the Abuse of Dominance: The Apple iPod iTunes Antitrust Litigation, https://www.law. ox.ac.uk/sites/files/oxlaw/761605008.pdf (dostęp: 25 III 2017); N.F. Sharpe, O.B. Arewa, Is Apple Playing Fair? Navigating the iPod FairPlay DRM Controversy , "Northwestern Journal of Technology and Intellectual Property" 2007, vol. 5, no. 2, s. 332 i n. 


\section{Technologiczne wiązanie produktów}

Innowacja może przybrać formę tzw. wiązania technologicznego (ang. technological tying), będącego jedną z form szeroko rozumianych tzw. transakcji wiązanych (ang. tying and bundling) ${ }^{78}$. Występuje ono wówczas, gdy odrębne produkty (komponenty) zostają ze sobą zintegrowane w taki sposób, że ich ewentualne rozdzielenie staje się niemożliwe lub też niepraktyczne ze względu na charakter i użyteczność produktu, jaki wspólnie tworzą ${ }^{79}$. Wiązanie technologiczne przyjmuje najczęściej formę klasycznej sprzedaży pakietowej, która polega na tym, że dwa lub więcej produktów oferowanych jest łącznie jako jeden, bardziej złożony produkt, przy czym w przypadku klasycznej sprzedaży pakietowej (ang. pure bundling) żaden z komponentów będących częścią pakietu nie jest dostępny na rynku samodzielnie, natomiast $\mathrm{w}$ wariancie mieszanej sprzedaży pakietowej (ang. mixed bundling) produkty udostępniane są również odrębnie, lecz wówczas ich łączna cena jest wyższa niż cena pakietu ${ }^{80}$. Wiązanie technologiczne kojarzone jest też z takim zaprojektowaniem produktu (podstawowego), że może on funkcjonować właściwie tylko w powiązaniu z komplementarnym produktem wytworzonym przez tego samego wytwórcę (produktem powiązanym $)^{81}$. Stosowanie transakcji wiązanych - szczególnie o charakterze technologicznym - może mieć pozytywny wpływ na rozwój dynamicznych i opartych na innowacji rynków ${ }^{82}$. Przykładowo, dzięki

${ }^{78}$ Mimo różnic, jakie cechują sprzedaż wiązaną (ang. tying) i pakietową (ang. bundling), w prawie i ekonomii traktuje się je często łącznie (ze względu na podobne skutki, jakie wywierają na konkurencję), jako specyficzne postaci zachowań rynkowych zaliczanych do zbiorczej kategorii transakcji wiązanych, mających na celu łączną sprzedaż dwóch lub więcej produktów, zob. I. Małobęcki, Sprzedaż wiazana i pakietowa jako potencjalne naruszenie europejskiego prawa konkurencji - ekonomiczna i prawna analiza problemu, Warszawa 2013, s. 8, oraz powołane tam źródła.

${ }^{79}$ I. Małobęcki, op. cit., s. 11-12; D.E. Gaynor, Technological Tying, Bureau of Economics, Federal Trade Commission, Working Paper 2006, no. 284, s. 1.

${ }^{80}$ I. Małobęcki, op. cit., s. 9-10.

${ }^{81}$ Zob. przypis 2 na s. 15 Komunikatu Komisji - wytyczne w sprawie priorytetów, którymi Komisja będzie się kierować przy stosowaniu art. 82 Traktatu WE w odniesieniu do szkodliwych działań o charakterze praktyki wyłączającej, podejmowanych przez przedsiębiorstwa dominujące (Dz.Urz. UE C 45 z 24 II 2009 r., dalej: Wytyczne Komisji), s. 7; D.E. Gaynor, op. cit., s. 1; S. Frattaroli, Dodging the Bullet Again: Microsoft III's Reformulation of the Foremost Technological Tying Doctrine, "Boston University Law Review" 2010, vol. 90, s. 1916.

${ }^{82}$ I. Małobęcki, op. cit., s. 41; D.E. Gaynor, op. cit., s. 22-23; G. Sagi, A Comprehensive Economic and Legal Analysis of Tying Arrangements, "Seattle University Law Review” 2014, 
integracji telefonu komórkowego z pocztą elektroniczną, przeglądarką sieciowa, cyfrowym aparatem fotograficznym, kamerą wideo etc. rozwinął się rynek smartfonów. Wpływ wiązania technologicznego na innowacyjność na danym rynku lub w danym sektorze gospodarki może jednak nieść za sobą również negatywne skutki ${ }^{83}$. Co więcej, zdaniem Komisji Europejskiej ryzyko antykonkurencyjnego zamknięcia dostępu do rynku wskutek sprzedaży wiązanej opartej na aspektach technicznych jest większe w porównaniu ze sprzedażą wiązaną opartą na warunkach umownych, a to dlatego, że odejście od tej pierwszej wymaga poniesienia wysokich kosztów (możliwości odsprzedaży produktów składających się na ofertę są tu ograniczone ${ }^{84}$. Osobnym problemem są trudności w ocenie, czy technologiczne wiązanie jest uzasadnione czy nie, czego egzemplifikacją może być opisany niżej przypadek praktyk Microsoftu $^{85}$. Zagrożeniem są zwłaszcza praktyki wiązania technologicznego dominantów rynkowych, skłonnych bronić posiadanej już dominacji na jednym rynku, czy nawet ją umacniać, a nadto - transferować (przenosić) tę przewagę na kolejne rynki ${ }^{86}$. Podejmowane przez nich intensywne i kapitałochłonne inwestycje w badania i rozwój mogą być zatem nastawione nie na rozwój dynamicznych i opartych na innowacjach rynków, ale na tworzenie barier wejścia na rynek dla nowych konkurentów lub barier ekspansji dla konkurentów już na nim obecnych ${ }^{87}$. $W$ rezultacie rozwój konkurencji na rynkach produktu wiążącego (podstawowego) i związanego może być poważnie utrudniony. Kontrahenci podmiotu dominującego są bowiem przymuszeni do dokonywania zakupu produktu związanego od dominanta, co ogranicza im możliwość dokonywania takich zakupów od innych podmiotów. Powstaje zatem

vol. 38, s. 6 i n.; D.S. Evans, M. Salinger, Why Do Firms Bundle and Tie? Evidence from Competitive Markets and Implications for Tying Law, "Yale Journal on Regulation" 2005, vol. 22, no. 1, s. 37 i n.; K.N. Hylton, M. Salinger, Tying Law and Policy: A Decision-theoretic Approach, "Antitrust Law Journal" 2001, vol. 69, no. 2, s. 469 i n.

${ }^{83}$ I. Małobęcki, op. cit., s. 42; E. Elhauge, Tying, Bundled Discounts, and the Death of the Single Monopoly Profit Theory, "Harvard Law Review" 2009, vol. 123, s. 399; J.P. Choi, Tying and Innovation: A Dynamic Analysis of Tying Arrangements, "The Economic Journal" 2004, vol. 114, no. 492, s. 83 i n.; W.S. Grimes, The Antitrust Tying Law Schism: A Critique of Microsoft III and a Response to Hylton and Salinger, "Antitrust Law Journal" 2002, vol. 70, no. 1, s. 199 i n.

${ }^{84}$ Wytyczne Komisji, pkt 53.

${ }^{85}$ A. Stawicki, Komentarz do art. 9, w: Ustawa o ochronie konkurencji i konsumentów. Komentarz, pod red. A. Stawickiego, E. Stawickiego, Warszawa 2016, s. 373.

${ }^{86}$ D.W. Carlton, M. Waldman, The Strategic Use of Tying to Preserve and Create Market Power in Evolving Industries, „RAND Journal of Economics” 2002, vol. 33, no. 2, s. 194 i n.

${ }^{87}$ I. Małobęcki, op. cit., s. 42; J.P. Choi, op. cit., s. 97 i n. 
bariera wejścia na rynek lub poważne utrudnienie w rozwoju konkurencji na rynku produktu związanego, a także wzmocnieniu ulega pozycja dominująca na rynku produktu wiążącego ${ }^{88}$. Technologiczne wiązanie produktów przez dominantów rynkowych może zatem wywoływać nie tylko skutki antykonkurencyjne (wykluczające), ale też eksploatacyjne, zmuszając kontrahentów dominanta do zachowań, które mogą być dla nich niekorzystne i na które nie zdecydowaliby się w warunkach konkurencji (odbiorcy mogliby bowiem preferować zakup każdego z produktów odrębnie i od innego producenta $)^{89}$.

Niewątpliwie najgłośniejszym przypadkiem antymonopolowych interwencji dotyczących technologicznego wiązania produktów są, godne miana prawniczej sagi, sprawy wytoczone przeciwko spółce Microsoft: (1) w Stanach Zjednoczonych, gdzie zakwestionowano praktykę kontraktowego i technologicznego wiązania z systemem operacyjnym Windows przeglądarki Internet Explorer (IE) ${ }^{90}$, oraz (2) w ówczesnej Wspólnocie Europejskiej (WE), gdzie z kolei zakwestionowano wiązanie z systemem Windows odtwarzacza plików multimedialnych Windows Media Player (WMP) ${ }^{91}$. Sprawy te zyskały status prawdziwych causes célèbres, które przejdą do historii stosowania prawa antymonopolowego $^{92}$. Wypracowane w Stanach Zjednoczonych teorie będące podstawą antymonopolowej kwalifikacji technologicznego wiązania produktów

${ }^{88}$ A. Stawicki, op. cit., s. 374; B. Nalebuff, Bundling as an Entry Barrier, "Quarterly Journal of Economics" 2004, vol. 119, no. 1, s. 159 i n.

${ }^{89}$ A. Stawicki, op. cit., s. 374; B. Targański, Komentarz do art. 9, w: Ustawa o ochronie konkurencji i konsumentów. Komentarz, pod red. T. Skocznego, Warszawa 2014, s. 480; K. Kohutek, Komentarz do art. 9, w: K. Kohutek, M. Sieradzka, Ustawa o ochronie konkurencji i konsumentów. Komentarz, Warszawa 2014, s. 397; wyrok polskiego Sądu Najwyższego z 5 I 2007 r., sygn. III SK 17/06, LEX nr 489018; G. Sagi, op. cit., s. 9 i n.

${ }^{90}$ Zob. cytowany już wyrok w sprawie United States v. Microsoft.

${ }^{91}$ Zob. decyzję KE z 24 III 2004 r. w sprawie COMP/C-3/37.792 Microsoft (dalej: "decyzja w sprawie Microsoft"), http://ec.europa.eu/competition/antitrust/cases/dec_ docs/37792/37792_4177_1.pdf (dostęp: 22 III 2017), oraz wyrok Sądu Pierwszej Instancji (SPI) z 17 IX 2007 r. w sprawie T-201/04 Microsoft v. Komisja (dalej: „wyrok w sprawie Microsoft"), Zb. Orz. 2007, s. II-03601; A.I. Gavil, H. First, The Microsoft Antitrust Cases: Competition Policy for the Twenty-first Century, Cambridge 2014; Sprawa Microsoft - studium przypadku. Prawo konkurencji na rynkach nowych technologii, pod red. D. Miąsika, T. Skocznego, M. Surdek, Warszawa 2008; W.H. Page, J.E. Lopatka, The Microsoft Case: Antitrust, High Technology, and Consumer Welfare, Chicago 2007.

${ }_{92}$ T. Skoczny, Sprawa Microsoft przed Komisja Europejską i Sadem Pierwszej Instancji, w: Sprawa Microsoft..., s. 42; D. Miąsik, Sprzedaż wiązana systemu operacyjnego Windows z oprogramowaniem użytkowym Windows Media Player, w: Sprawa Microsoft..., s. 125. Inna sprawa, że - jak sugerują obaj autorzy - przesadą byłoby kwalifikowanie rozstrzygnięć 
przez Microsoft zostały w dużej mierze przejęte przez WE ${ }^{93}$. O ile jednak sądy amerykańskie orzekły, że praktyka Microsoftu winna być oceniana nie na podstawie sztywnej reguły perse (zakładającej antykonkurencyjny z natury rzeczy charakter transakcji wiązanych), ponieważ mogłoby to zagrozić innowacyjności na rynkach technologii informatycznych, ale na podstawie elastycznej (jeśli nie amorficznej) reguły rozsądku, o tyle SPI nie odrzucił wprawdzie zastosowanej przez Komisję antymonopolowej kwalifikacji technologicznego wiązania produktów na podstawie kwalifikowanej reguły rozsądku (ang. structured rule of reason), jednakże podtrzymał prezentowane $\mathrm{w}$ dotychczasowym swoim orzecznictwie stanowisko zakładające quasi-bezwzględną (perse) nielegalność innych form wiązania produktów przez dominanta rynkowego ${ }^{94}$. W każdym razie z decyzji Komisji oraz wyroku SPI wynika wprost, że rozbudowa programów komputerowych (zarówno systemów operacyjnych, jak i programów użytkowych) o kolejne narzędzia użytkowe może stanowić antykonkurencyjne wiązanie w rozumieniu art. 102 TFUE (dawny art. 82 TWE $)^{95}$. Wiązanie zastosowane przez Microsoft godziło w konkurencję na rynku produktu związanego (odtwarzaczy multimedialnych). Umożliwiło ono tej spółce uzyskanie nieporównywalnej przewagi WMP nad konkurencyjnymi produktami i zagwarantowanie wszechobecności tego odtwarzacza w komputerach osobistych (PC) na całym świecie, zniechęcając tym samym użytkowników do korzystania z odtwarzaczy multimedialnych innych producentów, a producentów sprzętu - do preinstalowania takich odtwarzaczy na komputerach $\mathrm{PC}^{96}$. Antykonkurencyjny charakter wiązania zastosowanego przez Microsoft polegał też na ograniczeniu innowacyjności na rynku poprzez narzucenie swojego standardu. Wiązanie to wywołało (jak przyznał sam Microsoft) efekt standaryzacji platformy WMP. Nie kwestionując potencjalnych korzyści

w sprawie Microsoft zapadłych w UE do kanonu unijnego orzecznictwa w sprawach ochrony konkurencji (jako źródła nowych standardów orzeczniczych).

${ }^{93}$ K.N. Hylton, Microsoft After Fifteen Years, "Competition Policy International" 2015, vol. 11, no. 1, s. 6-7; M. Maggiolino, Intellectual Property and Antitrust: A Comparative Economic Analysis of US and EU Law, Cheltenham 2011, s. 139.

${ }^{94}$ J.F. Ponsoldt, C.D. David, Comparison Between U.S. and E.U. Antitrust Treatment of Tying Claims Against Microsoft: When Should the Bundling of Computer Software Be Permitted, "Northwestern Journal of International Law \& Business" 2007, vol. 27, no. 2, s. 425; N. Economides, I. Lianos, The Elusive Antitrust Standard on Bundling in Europe and in the United States in the Aftermath of the Microsoft Cases, "Antitrust Law Journal" 2009, vol. 76, no. 2, s. 524.

${ }^{95}$ Decyzja w sprawie Microsoft, pkt 792-989; wyrok w sprawie Microsoft, pkt 935;

D. Miąsik, Sprzedaż wiązana..., s. 128.

${ }^{96}$ Decyzja w sprawie Microsoft, pkt 843-954; wyrok w sprawie Microsoft, pkt 1054. 
(zwłaszcza kosztowych), jakie może przynieść standaryzacja, SPI podkreślił w uzasadnieniu wyroku, że nie można pozwolić na to, aby była ona jednostronnie narzucana przez dominanta w drodze sprzedaży wiązanej ${ }^{97}$. Konsekwencją uznania praktyki Microsoftu za naruszenie art. 82 TWE było nie tylko nałożenie na spółkę grzywny, ale także zastosowanie środka zaradczego, który w odniesieniu do praktyki nielegalnego wiązania produktów polegał na nakazaniu koncernowi Microsoft sprzedaży prawidłowo funkcjonującej wersji systemu operacyjnego Windows bez WMP, a zarazem zakazaniu podejmowania przez tę spółkę jakichkolwiek środków, które wywoływałyby skutek równoważny do "zintegrowania WMP z Windows” lub „sprzedaży wiązanej Windows z WMP ${ }^{\prime \prime 98}$. Dla porównania, wszczęte przez amerykańskie władze antymonopolowe postępowania przeciwko Microsoftowi zakończyły się ugodą (ang. consent decree), która nie przewidywała technologicznej separacji systemu Windows i przeglądarki IE, lecz zobowiązywała pozwaną spółkę m.in. do zapewnienia producentom komputerów PC możliwości instalowania programów użytkowych innych producentów niż Microsoft ${ }^{99}$. Trafna wydaje się supozycja jednego z komentatorów, że zarysowane odmienności w podejściu amerykańskich i wspólnotowych (obecnie unijnych) władz antymonopolowych do praktyk Microsoftu zdają się wskazywać, że tym pierwszym zależało bardziej, aby ich rozstrzygnięcia nie szkodziły innowacyjności amerykańskiego potentata informatycznego, niż służyły innowacyjności jego konkurentów, której wspieranie było z kolei motywem przewodnim działań władz wspólnotowych (unijnych) ${ }^{100}$.

\section{Zaniechanie udzielenia informacji warunkujących interoperacyjność konkurencyjnych produktów}

Niekiedy zdarza się, że wprowadzenie na rynek konkurencyjnego produktu wymaga uzyskania od przedsiębiorstwa wytwarzającego produkt komplementarny informacji dotyczących jego konstrukcji lub interfejsu

${ }^{97}$ Wyrok w sprawie Microsoft, pkt 1152.

${ }^{98}$ Decyzja w sprawie Microsoft, pkt 1011-1012; wyrok w sprawie Microsoft, pkt 1198.

${ }^{99}$ Szerzej T. Bagdziński, Wiazanie IE $z$ Windows na tle historii postępowań antytrustowych przeciwko Microsoftowi w Stanach Zjednoczonych, w: Sprawa Microsoft..., s. 152 i n.

${ }^{100}$ J. Apon, Cases Against Microsoft: Similar Cases, Different Remedies, „European Competition Law Review" 2007, vol. 28, s. 334. 
umożliwiających połączenie (interoperacyjność) z tym produktem. Jeśli dostawca produktu komplementarnego nie udzieli tych informacji lub zmieni konstrukcję produktu, nie informując o tym w odpowiednim czasie, może to skutkować uniemożliwieniem interoperacyjności tego produktu z produktami oferowanymi przez konkurentów, a tym samym zniweczeniem ich zdolności konkurencyjnych. W przypadku gdy zachowanie takie będzie przyczyniało się do utrwalenia lub poszerzenia władzy (dominacji) rynkowej, może stać się przedmiotem interwencji antymonopolowej. W sposób modelowy obrazuje to przywoływana już sprawa praktyk rynkowych Microsoftu, w której Komisja uznała, a stanowisko to następnie podzielił SPI, że spółka ta dopuściła się zakazanego art. 82 TWE nadużycia pozycji dominującej poprzez odmowę udostępnienia konkurentom informacji zapewniających interoperacyjność produkowanych przez nich systemów operacyjnych z systemem Windows oraz odmowę zezwolenia na wykorzystanie tych informacji w celu stworzenia, a następnie sprzedaży produktów konkurujących z produktami Microsoftu na rynku oprogramowania systemowego dla serwerów pracy grupowej ${ }^{101}$. Takie działanie Microsoftu stwarzało ryzyko wyeliminowania konkurencji z rynku systemów operacyjnych dla serwerów grup roboczych, ponieważ informacje, których udzielenia odmówiono, warunkują interoperacyjność konkurencyjnych produktów z platformą Windows, która stała się de facto standardem na rynku komputerów osobistych ${ }^{102}$. Odmowa Microsoftu nie była przy tym obiektywnie uzasadniona, a nadto ograniczała postęp techniczny ze szkodą dla konsumentów ${ }^{103}$. Ograniczanie postępu technicznego polegało w tym przypadku na utrudnianiu, lub wręcz uniemożliwianiu doskonalenia konkurencyjnych systemów operacyjnych. Brak interoperacyjności z powszechnie stosowaną platformą Windows powodował bowiem, że producenci konkurencyjnych systemów operacyjnych nie byliby w stanie ich sprzedać, nawet jeśli konsumenci ceniliby oferowane przez nie udoskonalenia, co w konsekwencji obniżało skłonność konkurentów Microsoftu do udoskonalania swoich produktów, ze szkodą dla konsumentów. Z tych też powodów Komisja zobowiązała spółkę do

${ }^{101}$ Decyzja w sprawie Microsoft, pkt 546-791; wyrok w sprawie Microsoft, pkt 101-776.

102 Decyzja w sprawie Microsoft, pkt 585-692; wyrok w sprawie Microsoft, pkt 30-32, 618-620.

${ }^{103}$ Decyzja w sprawie Microsoft, pkt 709-778, 693-708; M. Surdek, Odmowa Microsoftu przekazania konkurentom informacji zapewniających interoperacyjność ich systemów operacyjnych dla serwerów z platforma Windows, w: Sprawa Microsoft..., s. 67. 
udostępnienia informacji zapewniających interoperacyjność z platformą Windows każdemu przedsiębiorstwu zainteresowanemu opracowaniem i sprzedażą systemów operacyjnych dla serwerów i udzielenia mu licencji na korzystanie w takim właśnie celu z tych informacji. Licencja powinna być udzielona na rozsądnych i niedyskryminujących warunkach, a udostępniane informacje powinny być regularnie i na bieżąco aktualizowane ${ }^{104}$. Decyzja Komisji i wyrok SPI w sprawie Microsoft potwierdziły, że dostęp do informacji zapewniających interoperacyjność oprogramowania komputerowego jest niezbędny zwłaszcza w sytuacji, gdy jeden z programów staje się de facto standardem na rynku, a jego pozycja jest wzmacniana przez efekty sieciowe charakterystyczne zwłaszcza dla rynków technologii informatycznych ${ }^{105}$.

\section{Podsumowanie}

W świetle poczynionych uwag uprawniony staje się wniosek, nawiązujący do tytułowego pytania i użytej w nim figury retorycznej, że jakkolwiek brzmi to paradoksalnie, innowacje moga godzić w konkurencję. Tym samym są realnym wyzwaniem dla prawa antymonopolowego. O randze i skali trudności tego wyzwania oraz towarzyszących mu kontrowersjach świadczyć mogą meandry wysoce enigmatycznej i labilnej, jak dotąd, polityki stosowania prawa antymonopolowego do innowacji ${ }^{106}$. Zaiste wciąż próżno by szukać konsensusu w kwestii relacji między konkurencją a innowacjami, a także co do zasadności obejmowania tych ostatnich reżimem antymonopolowym, zwłaszcza gdy chodzi o stosowanie zakazu nadużywania pozycji dominującej (monopolizacji rynku) wobec innowacyjnych przedsięwzięć indywidualnych przedsiębiorstw. Szerokie spektrum zajmowanych w tym zakresie stanowisk obejmuje koncepcje bliskie przeciwstawnym teoriom Schumpetera i Arrowa oraz liczne poglądy pośrednie ${ }^{107}$. Zdaniem części komentatorów tempo postępu gospodarczego i towarzyszących mu procesów innowacyjnych jest współcześnie tak duże, że pozbawia pełnej skuteczności tradycyjne instrumenty prawa antymonopolowego

${ }^{104}$ Zob. decyzja w sprawie Microsoft, pkt 994-1010, 1054-1080; M. Surdek, op. cit., s. 68.

${ }^{105}$ M. Surdek, op. cit., s. 81.

106 Zob. D.A. Crane, op. cit., s. 7; G.A. Manne, J.D. Wright, Innovation and the Limits of Antitrust, "Journal of Competition Law \& Economics" 2010, vol. 6, no. 1, s. 156 i n.

${ }^{107}$ D.A. Crane, op. cit., s. 7; G.A. Manne, J.D. Wright, op. cit., s. 156. 
(świadczyć o tym ma choćby sprawa Microsoft) ${ }^{108}$. Inni z kolei twierdzą, że gdy w grę wchodzą innowacje i konkurencja dynamiczna, prawo antymonopolowe nie powinno być w ogóle stosowane ze względu na jego potencjalnie negatywny (zniechęcający) wpływ na innowacje ${ }^{109}$. Jeszcze inni utrzymuja że w realiach współczesnej gospodarki rośnie zagrożenie antykonkurencyjnymi nadużyciami, także mającymi związek z innowacjami, co wymaga wręcz wzmożonej aktywności władz antymonopolowych w tym obszarze ${ }^{110}$.

Ujawniający się $\mathrm{w}$ wypowiedziach wielu przedstawicieli doktryny i praktyki prawa antymonopolowego (zwłaszcza judykatury amerykańskiej) sceptycyzm co do możliwości (zasadności) kwalifikowania innowacji jako jednostronnego deliktu antykonkurencyjnego (nadużycia pozycji dominującej czy też przejawu monopolizacji rynku) ma wielorakie źródła. Jednym z nich jest wątpliwość, czy ekonomiści, a tym bardziej prawnicy, mają wystarczająco ugruntowane rozeznanie w kwestii relacji między dominacją rynkową a innowacjami, o których zgodności z regułami konkurencji mają orzekać ${ }^{111}$. Niebagatelną, jeśli nie kluczową, rolę odgrywa tu obawa, że obarczanie funkcjonariuszy organów antymonopolowych i sędziów analizą zarzutów (roszczeń) dotyczących potencjalnie antykonkurencyjnych innowacji wymagałoby posiadania przez te osoby techniczno-inżynieryjnych kompetencji, którymi osoby te nie dysponuja, a nadto że jakakolwiek interwencja antymonopolowa delegalizująca działalność innowacyjną (penalizująca innowatora) prowadziłaby do zastoju innowacji ${ }^{112}$. Nie bez znaczenia w tym kontekście jest też przekonanie, że innowacje potęgują ryzyko błędów antymonopolowych, i to w dwojakim sensie $^{113}$. Po pierwsze, innowacje zwiększają prawdopodobieństwo tego rodzaju błędów, a to dlatego, że z definicji wiążą się z wdrażaniem nowatorskich praktyk rynkowych lub innowacyjnych produktów, które - jak uczy historia - nie są traktowane z ufnością przez władze antymonopolowe, które zwykły przypisywać im antykonkurencyjne predylekcje, nawet jeśli

${ }^{108}$ Na przykład R.W. Crandall, C. Winston, Does Antitrust Policy Improve Consumer Welfare? Assesing the Evidence, "Journal of Economics Perspectives" 2003, vol. 17, no. 4, s. 3 i n.; C. Shapiro, Microsoft: A Remedial Failure, "Antitrust Law Journal” 2009, vol. 75, no. 3, s. 739 i n.

${ }^{109}$ Na przykład D.F. Spulber, Unlocking Technology: Antitrust and Innovation, "Journal of Competition Law \& Economics" 2008, vol. 4, no. 4, s. 915 i n.

${ }^{110}$ Na przykład C. Shapiro, Exclusivity..., s. 674 i n.

${ }^{111}$ D.A. Crane, op. cit., s. 1.

${ }^{112}$ Ibidem.

${ }^{113}$ G.A. Manne, J.D. Wright, op. cit., s. 164 i n. 
z czasem wiedza i doświadczenie weryfikują negatywnie tego rodzaju nastawienie ${ }^{114}$. Po drugie, koszty społeczne błędów antymonopolowych $\mathrm{w}$ sprawach dotyczących innowacji są $\mathrm{z}$ reguły wyższe $\mathrm{w}$ porównaniu $\mathrm{z}$ innymi sprawami. Teza ta opiera się na założeniu, którego najbardziej prominentnym eksponentem jest Frank Easterbrook, że istnieje fundamentalna asymetria między kosztami dwóch podstawowych typów błędów, które mogą się ujawniać w procesie implementacji prawa antymonopolowego. W myśl tego założenia tzw. błędy typu pierwszego (ang. false positive errors), polegające na delegalizacji zachowań rynkowych, które konkurencji nie naruszaja, są prawdopodobnie znacznie bardziej kosztowne w porównaniu z tzw. błędami typu drugiego (ang. false negative errors), tj. nieuzasadnioną tolerancją zachowań antykonkurencyjnych, a to dlatego, że sama gospodarka (a ściślej - mechanizm konkurencji) szybciej, sprawniej i efektywniej koryguje antykonkurencyjne defekty rynku aniżeli funkcjonariusze publiczni (władze antymonopolowe) ${ }^{115}$. Jak proroczo zauważył sędzia Easterbrook (już ponad trzy dekady temu), problem kosztownych błędów antymonopolowych jest szczególnie dotkliwy w obliczu "nowych metod wytwarzania i dystrybucji produktu"116. W kontekście innowacji problem błędów typu pierwszego może potęgować dodatkowo olbrzymia wartość innowacji technologicznych, a także zniechęcający wpływ błędnych interwencji antymonopolowych w obszarze innowacji na skłonność do angażowania się w przyszłości w podobne przedsięwzięcia innowacyjne ${ }^{117}$.

Przedstawiona argumentacja, oparta na teoretycznej analizie kosztów błędów antymonopolowych, choć niewolna od krytyki, wywarła przemożny wpływ na politykę antymonopolowa, zwłaszcza w Stanach Zjednoczonych ${ }^{118}$. Mimo to błędem byłoby bagatelizowanie, a tym

${ }^{114}$ Ibidem, s. 156 i 169 (autorzy twierdzą wręcz, że w polityce antymonopolowej nowe oznacza de facto złe i że jest ona wrogo nastawiona do innowacji).

${ }^{115}$ F.H. Easterbrook, The Limits of Antitrust, "Texas Law Review” 1984, vol. 63, no. 1, s. 1 i n.; zob. też F.S. McChesney, Easterbrook on Errors, "Journal of Competition Law \& Economics" 2010, vol. 6, no. 1, s. 11 i n.; A. Devlin, M. Jacobs, Antitrust Error, "William \& Mary Law Review" 2010, vol. 52, no. 1, s. 75 i n.; J.D. Wright, Abandoning Antitrust's Chicago Obsession: The Case for Evidence-Based Antitrust, "Antitrust Law Journal" 2012, vol. 78 , no. 1 , s. $248-249$.

${ }^{116}$ F.H. Easterbrook, op. cit., s. 5.

117 G.A. Manne, J.D. Wright, op. cit., s. 168 i 170. O zjawisku (efekcie) „chłodzenia” konkurencji (ang. chilling effect) generowanym przez błędy typu pierwszego zob. też K. Kohutek, Praktyki wykluczajace przedsiębiorstw dominujacych. Prawidłowość i stosowalność regut konkurencji, Warszawa 2012, s. 220 i n.

118 Zob. J.B. Baker, Taking the Error Out of "Error Cost" Analysis: What's Wrong with Antitrust's Right, "Antitrust Law Journal” 2015, vol. 80, no. 1, s. 1 i n. (autor przekonująco 
bardziej ignorowanie, ryzyka błędów typu drugiego i pokładanie przesadnej wiary w samoregulacyjne zdolności rynku, nawet jeśli wśród jej orędowników znaleźli się tak wybitni i wpływowi znawcy prawa antymonopolowego (reprezentujący konserwatywną szkołę chicagowską), jak Robert Bork czy wspomniany Frank Easterbrook ${ }^{119}$. Co prawda, jak to wyrazili dobitnie inni luminarze amerykańskiego prawa antymonopolowego, Phillip Areeda i Herbert Hovenkamp, "nawet monopolista ma prawo konkurować agresywnie i modyfikować swoje produkty w celu uczynienia ich bardziej atrakcyjnymi dla nabywców, nie mając żadnego obowiązku pomagania innym przedsiębiorstwom w utrzymaniu się lub umocnieniu na rynku"120, ale nie oznacza to - jak wynika choćby z kilku przedstawionych wyżej przypadków - że każde zachowanie rynkowe kojarzone $z$ innowacją zwiększa dobrobyt społeczno-gospodarczy i jest per se zgodne z regułami konkurencji lub też zasługuje na immunitet antymonopolowy. W konsekwencji bezproduktywne, a nawet szkodliwe „innowacje”, zwłaszcza przyjmujące postać praktyk stricte (bezwzględnie) drapieżnych, czy choćby "tylko" wykluczających, gdy wykluczenie to jest dostatecznie duże, a wartość nowości lub ulepszenia minimalna, winny być traktowane jako godne napiętnowania delikty antykonkurencyjne. W każdym jednak razie, zważywszy na pierwszoplanowy cel polityki gospodarczej, jakim powinno być wspieranie i promowanie innowacji, a także ze względu na okoliczność, że zadaniem prawa antymonopolowego jest nie tylko rozstrzyganie (ex post) realnych konfliktów w relacjach między innowacjami a ochroną konkurencji, ale także tworzenie (exante) klimatu sprzyjającego rozwojowi innowacji ${ }^{121}$, interwencje antymonopolowe w zakresie innowacji powinny być szczególnie rozważne, dalekowzroczne i przewidywalne. W przeciwnym wypadku prawo antymonopolowe może stać się dla aktualnych lub potencjalnych innowatorów ciężkim brzemieniem - nieledwie czymś w rodzaju mitycznego miecza Damoklesa.

polemizuje z poglądem eksponującym ryzyko błędów typu pierwszego, a umniejszającym ryzyko błędów typu drugiego w sprawach antymonopolowych).

119 Zob. R.H. Bork, The Antitrust Paradox: A Policy at War with Itself, New York 1978, s. 133; F. Easterbrook, op. cit., s. 2-3; J.B. Baker, Taking the Error..., s. 1 i n.

${ }^{120}$ P.E. Areeda, H. Hovenkamp, Antitrust Law: An Analysis of Antitrust Principles and Their Application, New York 2008, s. 304, cyt. za: S.R. Miller, M.S. Patel, Technological Tying and 'Predatory' Innovation, https://www.law360.com/articles/251514/technological-tyingand-predatory-innovation (dostęp: 25 III 2017).

${ }^{121}$ Zob. A. Jurkowska-Gomułka, T. Skoczny, A. Warzybok, op. cit., s. 188. 


\section{ANTICOMPETITIVE INNOVATIONS - OXYMORON OR A REAL CHALLENGE FOR ANTITRUST LAW?}

\section{S u m m a ry}

One of the overriding principles of modern economic policy is promotion of innovation. It also turns out, however, that innovations may work against competition, thus becoming a major challenge for antitrust law. The importance and the degree of difficulty surrounding this challenge as well as some controversies related to it can be evidenced by the antitrust enforcement policy referring to innovations. This policy has thus far been highly enigmatic and labile. It seems that no consensus can be reached on the relation between competition and innovations as much as it cannot be achieved on the validity of including the latter in the antitrust enforcement regime, particularly when it comes to applying the prohibition of the abuse of a dominant position. While it is true that innovations compound the risk of antitrust errors, especially those consisting in de-legalisation of innovations which are not anticompetitive, it would nevertheless be wrong to underestimate, and even more so to ignore, the risk of errors amounting to an unjustified tolerance of anticompetitive innovations and an overstated belief in the self-regulatory ability of the market. In any case, considering the priority objective of the economic policy which should be to support and promote innovations, as well as taking into account that the goal of antitrust law is not only to settle real conflicts arising between innovations and the protection of competition, but also to provide for an innovation-friendly environment, the antitrust intervention into innovations should be sensible, farsighted and predictable. Otherwise, antitrust law may become a burden for the actual and potential innovators - like the mythical sword above the head of Damocles.

Keywords: anticompetitive innovations - unilateral conduct restricting competition - antitrust law 